\title{
Orally Bioavailable Pyridine and Pyrimidine-Based Factor XIa Inhibitors: Discovery of the Methyl N-Phenyl Carbamate P2 Prime Group
}

James R. Corte*, Tianan Fang, Donald J. P. Pinto, Michael J. Orwat, Alan R. Rendina, Joseph M. Luettgen, Karen A. Rossi, Anzhi Wei, Vidhyashankar Ramamurthy, Joseph E. Myers Jr., Steven Sheriff, Rangaraj Narayanan, Timothy W. Harper, Joanna J. Zheng, Yi-Xin Li, Dietmar A. Seiffert, Ruth R. Wexler, and Mimi L. Quan

Bristol-Myers Squibb Company, Research and Development, P.O. Box 5400, Princeton, New Jersey 08543, United States

\section{ARTICLE INFO}

Article history:

Received

Received in revised form

Accepted

Available online

\section{Keywords:}

Factor XIa

FXIa

Thrombosis

Activated Partial Thromboplastin Time

aPTT

\section{ABSTRACT}

Pyridine-based Factor XIa (FXIa) inhibitor (S)-2 was optimized by modifying the P2 prime, P1, and scaffold regions. This work resulted in the discovery of the methyl N-phenyl carbamate P2 prime group which maintained FXIa activity, reduced the number of H-bond donors, and improved the physicochemical properties compared to the amino indazole P2 prime moiety. Compound $(S)-17$ was identified as a potent and selective FXIa inhibitor that was orally bioavailable. Replacement of the basic cyclohexyl methyl amine P1 in $(S)-\mathbf{1 7}$ with the neutral $p$ chlorophenyltetrazole P1 resulted in the discovery of $(S)-\mathbf{2 4}$ which showed a significant improvement in oral bioavailability compared to the previously reported imidazole $(S)$-23 Additional improvements in FXIa binding affinity, while maintaining oral bioavailability, was achieved by replacing the pyridine scaffold with either a regioisomeric pyridine or pyrimidine ring system.

2016 Elsevier Ltd. All rights reserved.

* James R. Corte. Tel.: +1-609-466-5030; fax: +1-609-818-3331; e-mail: james.corte@bms.com 


\section{Introduction}

Factor XIa (FXIa), the activated form of the zymogen FXI, is a trypsin-like serine protease and a key component in the intrinsic pathway of the blood coagulation cascade. A growing body of research indicates that FXIa plays a pivotal role in pathologic thrombosis (blood clots) but only a minor role in hemostasis. ${ }^{1}$ Genetic, ${ }^{2-5}$ preclinical, ${ }^{6-7,15}$ and recently published clinical data ${ }^{8}$ support the hypothesis that FXI and FXIa are targets for anticoagulant therapy.

In contrast to the severe bleeding episodes observed in individuals with either a Factor VIII deficiency (Hemophilia A) or Factor IX deficiency (Hemophilia B), individuals with a FXI deficiency (Hemophilia C) rarely experience abnormal or spontaneous bleeding. ${ }^{2}$ In fact, bleeding episodes which arise following an injury or surgery are generally characterized as mild or moderate for the majority of these FXI deficient individuals. Moreover, analyses have shown that individuals with a severe FXI deficiency have a lower risk for ischemic stroke and deepvein thrombosis (DVT). ${ }^{3}$ Similarly, individuals with elevated levels of FXI experience a higher incidence of acute myocardial infarction and DVT. ${ }^{4}$ The phenotype observed in FXI deficient individuals was recapitulated in FXI deficient mice. FXI deficient mice show reduced thrombus formation in venous and arterial thrombosis models without an increase in injury-related bleeding compared to wild-type mice. ${ }^{5}$

Inhibition of the zymogen FXI with either neutralizing antibodies or antisense oligonucleotides (ASO) was shown to be effective in a number of animal thrombosis models, including primates, with minimal effects on bleeding time. ${ }^{6,7}$ An antisense oligonucleotide (ISIS 416858) which blocks the expression of FXI is the most advanced in clinical trials. ${ }^{8}$ In a phase II study in total knee replacement, ISIS-416858 reduced the incidence of deep vein thrombosis and showed fewer bleeding events as compared to subcutaneously administered enoxaparin.

In addition to inhibiting FXI production, a number of research groups have targeted FXIa with either active site or allosteric inhibitors. $^{9-18}$ The active site irreversible FXIa inhibitors are represented by $\beta$-lactam (BMS-262084), $\alpha$-ketothiazole peptidomimetics, boronic acid peptidomimetics, and natural product clavatadine A. ${ }^{9-13}$ In 2013, Bristol-Myers Squibb (BMS)

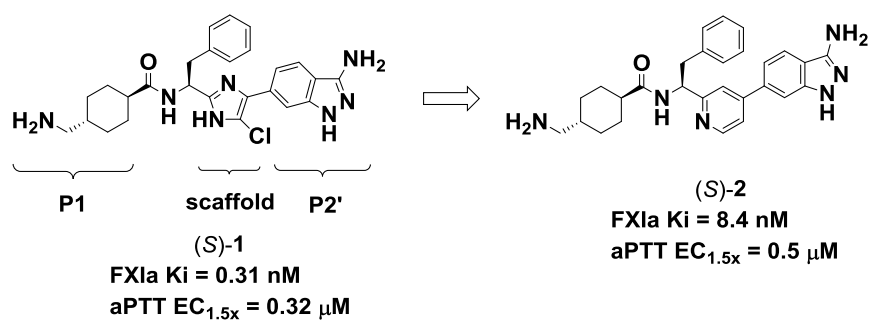

Figure 1. Imidazole and Pyridine-Based FXIa Inhibitors.

disclosed the first reversible FXIa inhibitor, based on a tetrahydroquinoline chemotype, which exhibited potent antithrombotic efficacy in a rabbit thrombosis model with minimal effects on cuticle bleeding. ${ }^{15}$ Recently BMS reported on the discovery of imidazole $(S)-\mathbf{1}$ (Figure 1), a picomolar FXIa inhibitor with excellent activity in the in vitro clotting assay $\left(\right.$ aPTT $\left.\mathrm{EC}_{1.5 \mathrm{x}}\right){ }^{16}$ Imidazole $(S)-\mathbf{1}$, which contains a basic cyclohexyl methyl amine $\mathrm{P} 1$ and amino indazole $\mathrm{P} 2$ prime, is a potent, selective, and reversible FXIa inhibitor, but it is not orally bioavailable. An intense effort was undertaken to address the lack of oral bioavailability and we recently disclosed that a modest improvement in oral bioavailability $\left(\% \mathrm{~F}_{\mathrm{dog}}=10\right)$ could be achieved. ${ }^{17}$ In an effort to discover structurally diverse FXIa inhibitors, replacements for the imidazole scaffold were investigated. It was found that the imidazole scaffold could be replaced with a variety of 6-membered heterocyclic rings and this work resulted in the discovery of pyridine $(S)$-2 (Figure 1), a single-digit nanomolar FXIa inhibitor which exhibited excellent potency in the in vitro clotting assay. ${ }^{18}$ The pyridine scaffold, as well as some of the other 6-membered ring heterocycles, may offer improved physicochemical properties compared to the imidazole ring and help address bioavailability issues. Herein we report on the optimization of the pyridine-based chemotype, focusing on modifications to the $\mathrm{P} 2$ prime, P1, and scaffold regions, which resulted in the discovery of compound $(S)-24$ which showed a significant improvement in oral bioavailability compared to the previously reported imidazole analogs.

\section{Results and discussion}

Pyridine $(S)$-2 is a single-digit nanomolar FXIa inhibitor which exhibited good potency in the in vitro clotting assay (aPTT $\mathrm{EC}_{1.5 \mathrm{x}}$ ) but is not orally bioavailable. The lack of oral bioavailability was attributed to the overall number of $\mathrm{H}$-bond donors present in the molecule, of which both the amino indazole P2 prime and the basic cyclohexyl methyl amine P1 moieties were major contributors. The strategy to improve oral bioavailability for the pyridine series was two-fold; 1) optimization of the amino indazole P2 prime moiety and 2) replacement of the basic cyclohexyl methyl amine P1 with a neutral $p$-chlorophenyltetrazole P1.
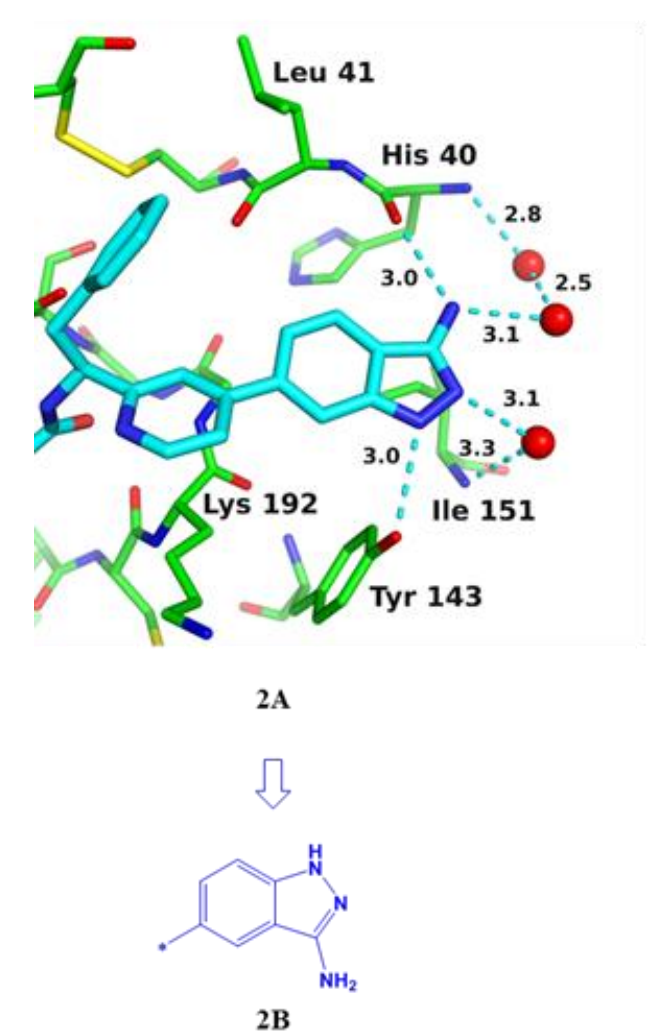

Figure 2. 2A. The S2 prime pocket of FXIa from the X-ray crystal structure of $(S)-2$ in FXIa. Key H-bonding interactions (dotted lines) between the amino indazole moiety and the FXIa residues His40, Tyr143, and Ile151 are shown. The red spheres depict water molecules. 2B. Regioisomeric 6,5fused amino indazole. 


\subsection{Optimization of the Amino Indazole P2 Prime Moiety: Bicyclic P2 Prime Groups.}

The amino indazole $\mathrm{P} 2$ prime group is a key binding element providing a 30-fold increase in FXIa activity in the pyridine series. ${ }^{18}$ X-ray crystallography of pyridine (S)-2 in the FXIa active site revealed that all three $\mathrm{N}-\mathrm{H}$ bonds of the amino indazole were engaged in hydrogen bonding interactions (Figure 2A). Specifically, one of the $\mathrm{NH}$ bonds from the $\mathrm{C} 3$-amino group forms an $\mathrm{H}$-bond with the backbone carbonyl of His40 (3.0 A) and the other $\mathrm{NH}$ forms an $\mathrm{H}$-bond with the $\mathrm{NH}$ of His40 via a network of water molecules. The indazole $\mathrm{N}(1) \mathrm{H}$ serves as an $\mathrm{H}$-bond donor to Tyr143 (3.0 $\AA$ ) and the $\mathrm{N}(2)$ forms an H-bond through a conserved water to Ile151 (3.1 $\AA$ and $3.3 \AA$ ). We probed these hydrogen bonds to determine which interactions were critical for FXIa activity and if any of the NH bond donors could be removed while maintaining FXIa activity and improving oral bioavailability of the pyridine series. The results of this exploration are described in Table 1.

Table 1. Compounds Containing Bicyclic P2 Prime Groups

$( \pm)_{( \pm)-6}$

${ }^{a} \mathrm{Ki}$ values were obtained from purified human enzyme and were averaged from multiple determinations $(n=2)$, as described in Ref. 15b. baPTT (activated partial thromboplastin time) in vitro clotting assay was performed in human plasma as described in Ref. $15 \mathrm{~b} .{ }^{\mathrm{c}} \mathrm{NT}=$ Not tested

In order to quickly survey the P2 prime region of FXIa, racemic derivatives were initially synthesized. When potent inhibitors were identified, the corresponding chiral, nonracemic derivatives were prepared prior to profiling. Both racemic $( \pm)-2$ and the active enantiomer (S)-2 are included in Table 1 for comparison. Removal of the 3 -amino group gave indazole $( \pm)-\mathbf{3}$ $($ FXIa $=87 \mathrm{nM})$ which led to a 6.5 -fold loss in FXIa activity. A similar loss in FXIa activity was observed when the 3-amino moiety was replaced with a 3-hydroxy group which afforded the 3-hydroxy indazole analog $( \pm)-4($ FXIa $=97 \mathrm{nM})$. The loss in FXIa activity in $( \pm)-4$ could be attributed to the electrostatic repulsion between the 3-hydroxy moiety and either His40 or the water molecules. ${ }^{19}$ Compounds $( \pm)-3$ and $( \pm)-\mathbf{4}$ demonstrated the importance of maintaining an $\mathrm{H}$-bond donor interaction with
His40. Based on the X-ray crystal structure, the indazole $\mathrm{N}(1) \mathrm{H}$ serves as an H-bond donor with Tyr143. Replacing the H-bond donor in $( \pm)$-2 with an $\mathrm{H}$-bond acceptor as found in 3-amino benzisoxazole $( \pm)-5 \quad($ FXIa $=9.2 \mathrm{nM})$, led to a modest improvement in FXIa activity. The corresponding chiral, nonracemic derivative $(\mathrm{S})-\mathbf{5}^{20}$ (FXIa $\mathrm{Ki}=3.8 \mathrm{nM}$ ) was 2-fold more active than the indazole (S)-2 in FXIa binding but it was equipotent in the in vitro clotting assay $\left(\mathrm{aPTT} \mathrm{EC}_{1.5 \mathrm{x}}\right)$. Based on the potency of 3-amino benzisoxazole (S)-5, it appears that an $\mathrm{H}$ bond acceptor for Tyr143 is preferred. Switching from the 6,5fused bicycle to a 6,6-fused bicycle, while maintaining the $\mathrm{H}$ bond donors for His 40 on top and an H-bond acceptor for Tyr143 on the bottom, led to 4-aminoquinazoline $( \pm)-6$. The 4aminoquinazoline (FXIa $\mathrm{Ki}=10 \mathrm{nM}$ ) maintained FXIa activity but led to a loss in potency in the in vitro clotting assay. The importance of the H-bond acceptor for binding to Tyr143 is highlighted in 1-amino isoquinoline $( \pm)$-7. Removal of the nitrogen led to a $>10$-fold loss in FXIa activity. Based on the analogs described in Table 1, only the 3-amino benzisoxazole derivative (S)-5 allowed for the removal of one $\mathrm{H}$-bond donor while maintaining both FXIa activity and potency in the in vitro clotting assay.

Table 2. Compounds Containing Regioisomeric 6,5-Fused Bicyclic P2 Prime Groups

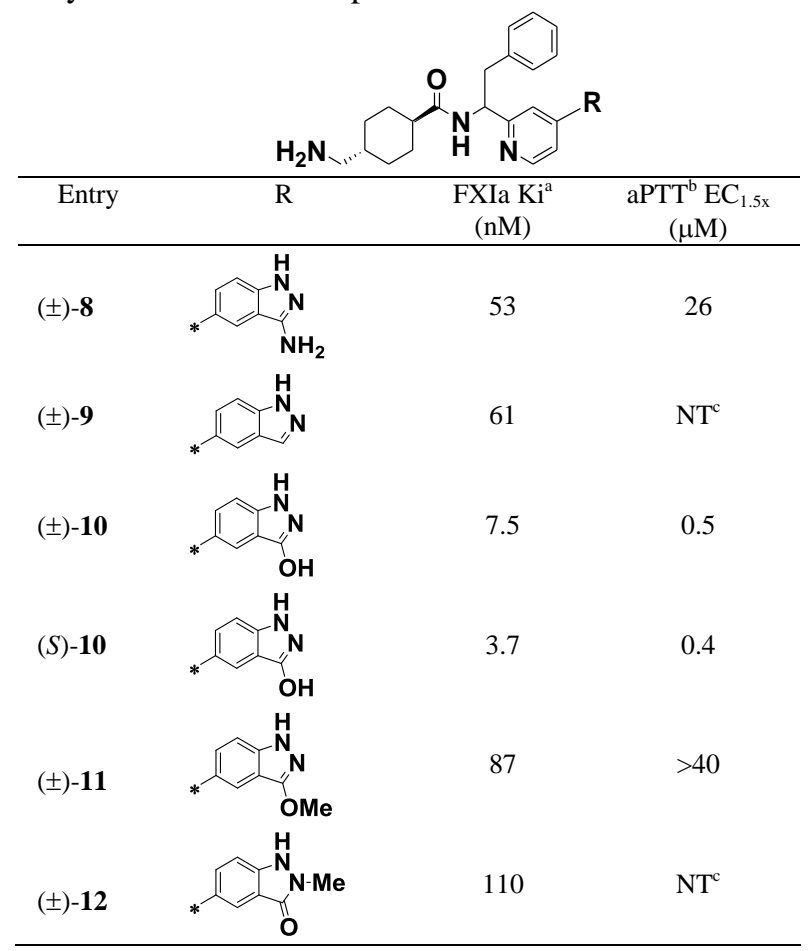

${ }^{\mathrm{a}} \mathrm{Ki}$ values were obtained from purified human enzyme and were averaged from multiple determinations $(n=2)$, as described in Ref. 15b. baPTT (activated partial thromboplastin time) in vitro clotting assay was performed in human plasma as described in Ref. $15 \mathrm{~b} .{ }^{\mathrm{c}} \mathrm{NT}=$ not tested.

\subsection{Regioisomer Bicyclic P2 Prime Groups.}

To confirm the optimal orientation of the $\mathrm{P} 2$ prime group, we prepared the regioisomeric 6,5-fused heterocycles (Table 2). We reasoned that if the 3 -amino indazole in (S)-2 were flipped $180^{\circ}$, the indazole $\mathrm{N}(1) \mathrm{H}$ could form an $\mathrm{H}$-bond to the carbonyl of His40 and the 3-amino moiety could form an H-bond to Tyr143 (Figure 2B). However, in this orientation the 3-amino indazole $( \pm)-8$ (FXIa $\mathrm{Ki}=53 \mathrm{nM}$ ) was 4 -fold less active than $( \pm)-2$. In fact, the 3-amino group did not influence FXIa activity as indazole ( \pm )-9 was equipotent to $( \pm)-8$. FXIa activity was improved by replacing the 3-amino moiety with a hydroxyl, which gave 3-hydroxy indazole $( \pm)-10$. The chiral, nonracemic derivative $(\mathrm{S})-\mathbf{1 0}$ (FXIa $\mathrm{Ki}=3.7 \mathrm{nM}$ ) was approximately 2 -fold 
more potent than amino indazole (S)-2. Since the 3-hydroxy indazole can exist as the 3-oxo tautomer, it was unclear which functionality, the 3-hydroxy or the 3-oxo, was important for FXIa activity as each could serve as an H-bond acceptor for Tyr143. ${ }^{19}$ In an attempt to answer this question, the 3-OMe indazole ( \pm )-11 and the 3-oxo derivative $( \pm)-12$ were prepared. However, both modifications led to a $>10$-fold loss in FXIa activity. With the regioisomeric 6,5-fused heterocycles, only the 3-hydroxy indazole derivative (S)-10 allowed for the removal of one $\mathrm{H}$-bond donor while maintaining FXIa activity and potency in the in vitro clotting assay.

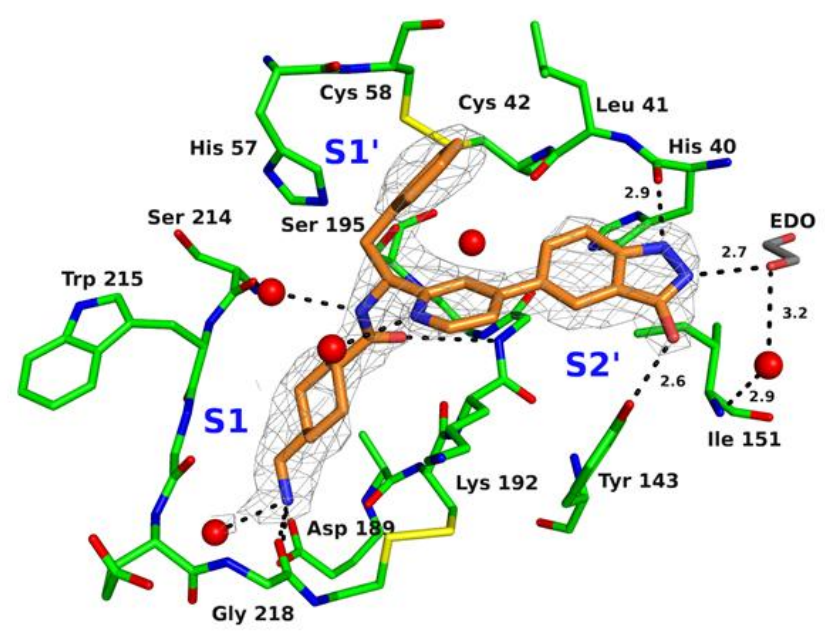

Figure 3. X-ray crystal structure of $(S)-\mathbf{1 0}$ in Factor XIa. PDB deposition number is 5EXL. The red spheres depict water molecules and the dotted lines depict hydrogen bonds. EDO stands for ethylene diol.

An X-ray structure of 3-hydroxy indazole $(S)$-10 bound to FXIa (2.3 Å resolution, R-work was 0.194 and R-free was 0.238 , Figure 3) was obtained. The binding mode was similar to that described previously for the pyridine $(S)-2$, with the exception of the P2 prime region. ${ }^{18}$ Compound $(S)-\mathbf{1 0}$ occupies the $\mathrm{S} 1, \mathrm{~S} 1$ prime, and the $S 2$ prime binding pockets and participates in a large number of hydrogen bonding interactions. The cyclohexyl methyl amine P1 occupies the S1 pocket where the primary amine is within bonding distance to either a conserved water molecule (2.7 ̊), Asp189 (2.9 ̊), Ala190 (3.0 ̊), or Gly218 $(3.0 \AA)$. The NH of the carboxamide forms an H-bond to Ser214 via a network of conserved water molecules. The carbonyl of the amide interacts with the oxyanion hole which consists of the backbone NH's of Ser195 (3.6 ̊), Asp194 and Gly193 (3.3 Å). The inhibitor's benzyl moiety occupies the S1 prime pocket with an edge-on hydrophobic interaction between the phenyl ring and the disulfide bridge Cys58-Cys42. The pyridine nitrogen forms an H-bond to a conserved water molecule (2.9 $\AA$ ). The 3-hydroxy indazole occupies the $\mathrm{S} 2$ prime pocket and engages in a number of H-bonds. The hydroxy group forms an H-bond with Tyr143 (2.6 $\AA$ ), the indazole $\mathrm{N}(1) \mathrm{H}$ forms an $\mathrm{H}$-bond to the backbone carbonyl of His40 (2.9 $\AA$ ), and the indazole $\mathrm{N}(2)$ forms an $\mathrm{H}$ bond to the Ile151 via ethylene diol (EDO) and a water molecule. $^{21}$

\subsection{Monocyclic P2 Prime Groups.}

The 3-hydroxy indazole $(S)$-10 was one of the most potent P2 prime groups discovered in this series. In order to maintain the interactions with His40 and Tyr143, we envisioned that an anthranilic acid moiety could mimic the 3 -hydroxy indazole. ${ }^{22}$ Indeed, anthranilic acid $( \pm)-\mathbf{1 3}(\mathrm{FXIa}=5.3 \mathrm{nM})$ was found to be equipotent to hydroxy indazole $(S)$-10 leading to further exploration of monocyclic P2 prime groups (Table 3). Removal of either the amino group in compound $( \pm)-\mathbf{1 4}$ or the carboxylic acid group in compound ( \pm )-15 led to a loss in FXIa activity.

Table 3. Compounds Containing Monocyclic P2 Prime Groups

$( \pm)-\mathbf{1 7}$

${ }^{\mathrm{a}} \mathrm{Ki}$ values were obtained from purified human enzyme and were averaged from multiple determinations ( $\mathrm{n}=2)$, as described in Ref. 15b. ${ }^{\mathrm{b}}$ aPTT (activated partial thromboplastin time) in vitro clotting assay was performed in human plasma as described in Ref. $15 \mathrm{~b} .{ }^{\mathrm{c}} \mathrm{NT}=$ not tested.

Between these two compounds, the $p$-amino group was more important for FXIa binding demonstrating the importance of $\mathrm{H}$ bond donation to His40. In order to improve the H-bond donating ability of the aniline, amino pyridine $( \pm)-\mathbf{1 6}$ and methyl N-phenyl carbamate $( \pm)$-17 were prepared. Amino pyridine $( \pm)$ 16 provided a 2 -fold increase in FXIa binding. Conversion of the $p$-amino group in $( \pm)$-15 to methyl carbamate $( \pm)$-17 (FXIa $=12$ $\mathrm{nM}$ ) provided a 4 to 5 -fold improvement in FXIa activity. The corresponding chiral, nonracemic derivative $(S)$-17 $($ FXIa $\mathrm{Ki}=$ $6.3 \mathrm{nM}$ ) was found to be a single-digit nanomolar FXIa inhibitor and showed good activity in the in vitro clotting assay. Analog $(S)$-17 showed similar FXIa inhibition as amino indazole $(S)$-2 and was approximately 2-fold less active than either 3-amino benzisoxazole $(S)-5$ or 3-hydroxy indazole $(S)-10$. Importantly, the methyl $N$-phenyl carbamate P2 prime moiety allowed for removal of two $\mathrm{NH}$ bond donors while maintaining FXIa activity when compared to amino indazole $(S)$-2.

An X-ray structure of methyl $N$-phenyl carbamate $(S)$-17 bound to FXIa (2.1 $\AA$ resolution, R-work was 0.194 and R-free was 0.226 , Figure $4 \mathrm{~A}$ ) was obtained. The overall binding mode is similar to that described for 3-hydroxy indazole $(S)-\mathbf{1 0}$, with the exception of the $\mathrm{P} 2$ prime region. As a result, only $\mathrm{P} 2$ prime interactions will be described here. The methyl $N$-phenyl carbamate of $(S)-\mathbf{1 7}$ occupies the $\mathrm{S} 2$ prime pocket with the NH of the carbamate forming an $\mathrm{H}$-bond with the carbonyl of His40 (2.8 $\AA$ ). The carbonyl of the carbamate forms an H-bond through a conserved water to Ile151 $(2.7 \AA)$. Figure $4 \mathrm{~B}$ shows an overlay of the X-ray structures of amino indazole $(S)$-2 and methyl $N$ - 
phenyl carbamate $(S)-\mathbf{1 7}$ in the S2 prime pocket of FXIa. The methyl $\mathrm{N}$-phenyl carbamate $(S)$-17 maintains two of the key Hbonding interactions seen with the amino indazole $(S)-\mathbf{2}$.

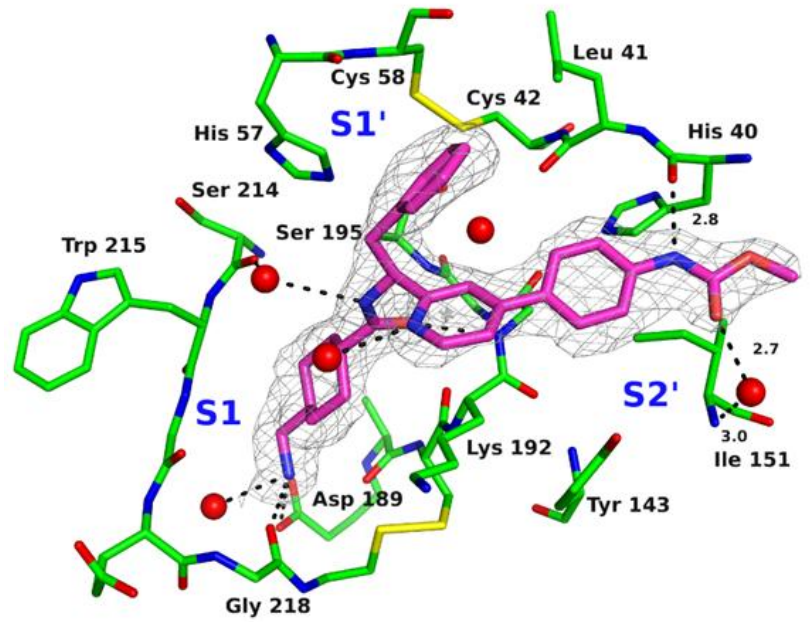

4A

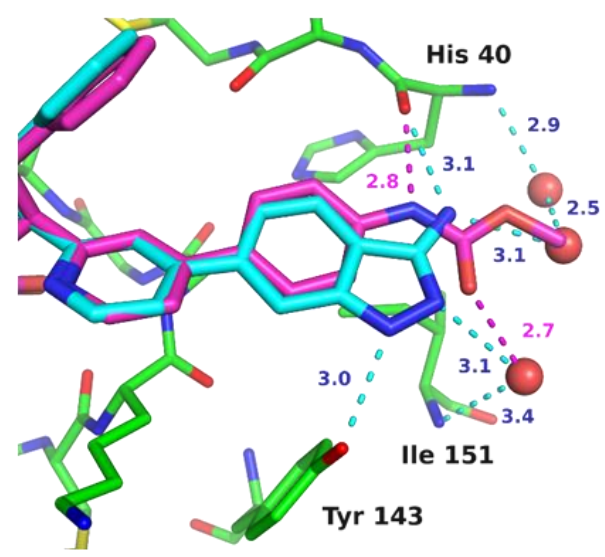

4B

Figure 4. 4A. X-ray crystal structure of $(S)-17$ in Factor XIa. PDB deposition number is 5EXM. 4B. Overlay of X-ray crystal structures of $(S)$ 17 (magenta) and (S)-2 (cyan) in the S2 prime pocket of Factor XIa. The red spheres depict water molecules and the dotted lines depict hydrogen bonds.

\subsection{Scaffold Optimization.}

The methyl $N$-phenyl carbamate $(S)$-17 exhibited good potency in the in vitro clotting assay but it remains 5-fold less potent than amino indazole $(S)$-2. The reason $(S)$-17 was less active in the clotting assay was postulated to be due to higher protein binding. ${ }^{23}$ To address the need for additional potency in the clotting assay we sought to lower the protein binding by replacing the pyridine scaffold with other 6-membered rings. ${ }^{18}$ The methyl $N$-phenyl carbamate P2 prime group was combined with phenyl, regioisomeric pyridines, pyrimidine, and pyridinone scaffolds (Table 4). The phenyl derivative $(S)$-18 was 2 to 3 -fold less active than pyridine $(S)-\mathbf{1 7}$ and showed a 5-fold loss in the clotting assay. The regioisomeric pyridines, $(S)-\mathbf{1 9}$ and $(S)-\mathbf{2 0}$, and the pyrimidine $(S)-21$ were essentially equipotent to $(S)-\mathbf{1 7}$ in the FXIa binding assay and they showed a 2 to 3 -fold improvement in potency in the clotting assay. The pyridinone (S)-22 (FXIa Ki $=2.4 \mathrm{nM}$; aPTT $\mathrm{EC}_{1.5 \mathrm{x}}=0.4 \mu \mathrm{M}$ ) was the only scaffold which showed improvements in both FXIa affinity (2.5fold) and potency in the clotting assay (6.5-fold) compared to pyridine $(S)-17 .^{24}$ Importantly, a variety of 6-membered ring scaffolds, specifically regioisomeric pyridines, pyrimidine, and pyridinone, were identified which improved the potency in the clotting assay.

Table 4. Compounds Containing Phenyl, Regioisomeric Pyridines, Pyrimidine, and Pyridinone Scaffolds With Basic P1.

\begin{tabular}{|c|c|c|c|}
\hline Entry & $\mathrm{X}$ & $\begin{array}{l}\begin{array}{l}\text { FXIa Ki } \\
(\mathrm{nM})\end{array} \\
\end{array}$ & $\begin{array}{l}\mathrm{aPTT}^{\mathrm{b}} \mathrm{EC}_{1.5 \mathrm{x}} \\
(\mu \mathrm{M})\end{array}$ \\
\hline$(S)-\mathbf{1 7}$ & & 6.3 & 2.6 \\
\hline & & 17 & 13 \\
\hline$(S)-19$ & & 8.4 & 1.3 \\
\hline$(S)-\mathbf{2 0}$ & & 7.9 & 0.9 \\
\hline$(S)-\mathbf{2 1}$ & & 9.1 & 1.2 \\
\hline$(S)-22$ & 0 & 2.4 & 0.4 \\
\hline
\end{tabular}

${ }^{\mathrm{a}} \mathrm{Ki}$ values were obtained from purified human enzyme and were averaged from multiple determinations $(\mathrm{n}=2)$, as described in Ref. $15 \mathrm{~b}$. ${ }^{\mathrm{b}} \mathrm{aPTT}$ (activated partial thromboplastin time) in vitro clotting assay was performed in human plasma as described in Ref. 15b.

\subsection{Replacement of the Basic Cyclohexyl Methyl Amine P1.}

Recently we reported that when the basic cyclohexyl methyl amine P1 was replaced with a neutral $p$-chlorophenyltetrazole P1, as exemplified in imidazole $(S)-\mathbf{2 3}$, a modest improvement in oral bioavailability was achieved (Table 5 and Table 6). ${ }^{17}$ As a result, the basic $\mathrm{P} 1$ in $(S)-\mathbf{1 7}$ was replaced with the neutral $p$ chlorophenyltetrazole $\mathrm{P} 1$ to give $(S)$-24. This modification resulted in only a 3-fold loss in FXIa activity (FXIa Ki $=23 \mathrm{nM})$

Table 5. Compounds Containing Imidazole, Regioisomeric Pyridines, Pyrimidine, and Pyridinone Scaffolds With Neutral P1.

\begin{tabular}{|c|c|c|c|}
\hline Entry & $\mathrm{X}$ & $\begin{array}{l}\text { FXIa Ki }^{\mathrm{a}} \\
(\mathrm{nM})\end{array}$ & $\begin{array}{l}\mathrm{aPTT}^{\mathrm{b}} \mathrm{EC}_{1.5 \mathrm{x}} \\
(\mu \mathrm{M})\end{array}$ \\
\hline$(S)-\mathbf{2 3}$ & & 6.7 & 8.6 \\
\hline$(S)-\mathbf{2 4}$ & & 23 & $>40$ \\
\hline (S)-25 & & 11 & 26 \\
\hline$(S)-26$ & & 6.7 & 21 \\
\hline$(S)-27$ & & 2.4 & 2.8 \\
\hline
\end{tabular}

${ }^{\mathrm{a}} \mathrm{Ki}$ values were obtained from purified human enzyme and were averaged from multiple determinations $(\mathrm{n}=2)$, as described in Ref. 15b. baPTT (activated partial thromboplastin time) in vitro clotting assay was performed in human plasma as described in Ref. 15b. 
however, a more significant loss (>15-fold) in potency in the clotting assay was observed. The basic P1 was also replaced with a $p$-chlorophenyltetrazole in the regioisomeric pyridine, pyrimidine, and pyridinone analogs. As shown in Table 5, the regioisomeric pyridine $(S)$-25, pyrimidine $(S)$-26, and pyridinone $(S)-27$ improved both FXIa binding activity and potency in the clotting assay compared to pyridine $(S)$-24. However, these compounds were less potent in the clotting assay than the corresponding analogs in Table 4 when the P1 moiety was the basic cyclohexyl methyl amine. The loss of potency in the clotting assay was a common feature on going from the basic cyclohexyl methyl amine $\mathrm{P} 1$ to the neutral $p$ chlorophenyltetrazole P1 and it was postulated that the loss was due to an increase in protein binding. ${ }^{23}$

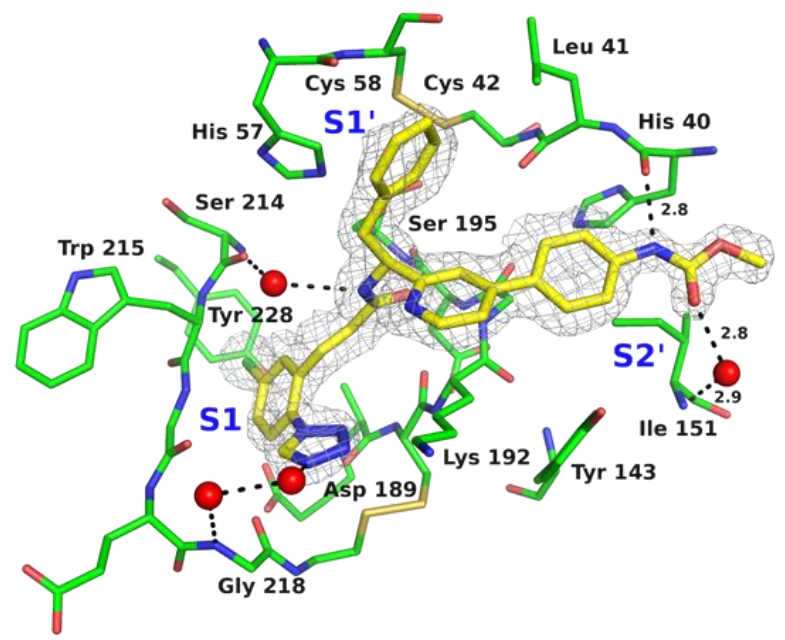

Figure 5. X-ray crystal structure of $(S)-24$ in Factor XIa. PDB deposition number is $5 E X N$. The red spheres depict water molecules and the dotted lines depict hydrogen bonds.

An X-ray structure of $(S)$-24 bound to FXIa (1.49 ̊ resolution, R-work was 0.170 and R-free was 0.196, Figure 5) was obtained. The overall binding mode is similar to that described for $(S)-\mathbf{1 7}$, with the exception of the P1 region. As a result, only the chlorophenyltetrazole P1 interactions will be described here. The chlorophenyl portion fills the S1 pocket with the chlorine atom forming a $\pi-\mathrm{Cl}(3.7 \AA)$ interaction with Tyr228. The tetrazole portion extends out of the S1 pocket and interacts with the Cys219-Cys191 disulfide bridge. ${ }^{25}$ In addition, the tetrazole N4 nitrogen forms an $\mathrm{H}$-bond, via a series of water molecules, to Gly218.

\subsection{Pharmacokinetic Profiles.}

Several compounds were evaluated in dog, using cassette dosing, in order to determine the pharmacokinetic (PK) profiles (Table 6). ${ }^{26}$ Amino indazole $(S)-2$ was found to be a high clearance compound and showed no oral exposure. However, replacing the P2 prime of amino indazole $(S)-2$ with a methyl $N$ phenyl carbamate, $(S)-\mathbf{1 7}$, improved oral exposure in $\operatorname{dog}(\% \mathrm{~F}=$ 63), albeit with both high clearance and high volume of distribution. Similarly, pyrimidine analog $(S)-21$ was shown to be orally bioavailable in $\operatorname{dog}(\% \mathrm{~F}=66)$ but was also a high clearance and high volume of distribution compound. Pyridinone $(S)-22$ exhibited both a lower clearance and lower volume of distribution relative to either $(S)$-17 or $(S)$-21 but it was not orally bioavailable. Even though the PK profiles for $(S)$-17 and $(S)-21$ were less than ideal with the high clearance and high volume of distribution, it was encouraging to see oral exposure with analogs containing the basic cyclohexyl methyl amine P1. Coupled with the fact that a modest improvement in oral bioavailability was achieved with imidazole $(S)-\mathbf{2 3}$, by replacing the basic cyclohexyl methyl amine P1 with a neutral $p$ chlorophenyltetrazole P1, we next evaluated pyridine $(S)$-24, regioisomeric pyridine $(S)$-25, pyrimidine $(S)$-26, and pyridinone $(S)$-27 which possessed the neutral $p$-chlorophenyltetrazole P1. Pyridine (S)-24 exhibited a low clearance, a long half-life, a high volume of distribution, and was orally bioavailable in $\operatorname{dog}[\% \mathrm{~F}=$ 34 (cassette); 53 (discrete)]. In comparing $(S)$-24 to $(S)-\mathbf{1 7}$, replacing the basic $\mathrm{P} 1$ with a neutral $\mathrm{P} 1$ led to improvements in both clearance and half-life while maintaining oral exposure. In comparing pyridine $(S)$-24 to imidazole $(S)$-23, the pyridine scaffold showed a lower clearance and longer half-life which resulted in a significant improvement in oral exposure. Regioisomeric pyridine $(S)-\mathbf{2 5}$ and pyrimidine $(S)-\mathbf{2 6}$ had a similar PK profile to $(S)-\mathbf{2 4}$, with low clearance, long half-life, and oral bioavailability $(\% \mathrm{~F}=28-34)$. The low clearance and long half-life of $(S)$-24, $(S)$-25, and $(S)$-26 could be due to higher protein binding which would be expected based on the potency in the clotting assay (aPTT $\mathrm{EC}_{1.5 \mathrm{x}}$ ). Replacing the basic P1 with the neutral P1 did not provide a general solution for improving the PK profile, as pyridinone $(S)$-27 showed high clearance, a short half-live, and a significant loss in oral exposure.

Table 6. Pharmacokinetic Profile For Selected Compounds.

\begin{tabular}{lllllll}
\hline Entry & $\begin{array}{l}\mathrm{Cl}^{\mathrm{a}} \\
(\mathrm{mL} / \mathrm{h} / \mathrm{kg})\end{array}$ & $\begin{array}{l}\mathrm{t}_{1 / 2} \\
(\mathrm{~h})\end{array}$ & $\begin{array}{l}\mathrm{Vdss} \\
(\mathrm{L} / \mathrm{kg})\end{array}$ & $\begin{array}{l}\mathrm{F} \\
(\%)\end{array}$ & $\begin{array}{l}\text { AUC } \\
\left(\mathrm{nM}{ }^{*} \mathrm{~h}\right)\end{array}$ & $\begin{array}{l}\text { Dose } \\
\text { iv/po }(\mathrm{mpk})\end{array}$ \\
\hline$(S)-\mathbf{2}$ & 50 & 1.2 & 3.4 & 0 & 0 & $0.27 / 0.43$ \\
$(S)-\mathbf{1 7}$ & 54 & 2.7 & 10 & 63 & 194 & $0.28 / 0.62$ \\
$(S)-\mathbf{2 1}$ & 27 & 3.2 & 5.4 & 66 & 195 & $0.20 / 0.29$ \\
$(S)-\mathbf{2 2}$ & 17 & 1.1 & 0.8 & $<1$ & 10 & $0.40 / 0.80$ \\
$(S)-\mathbf{2 3}$ & 21 & 2.4 & 3.4 & 10 & 30 & $0.20 / 0.20$ \\
$(S)-\mathbf{2 4}$ & 6.1 & 8.0 & 3.9 & 34 & 267 & $0.25 / 0.20$ \\
$(S)-\mathbf{2 5}$ & 5.6 & 3.7 & 1.6 & 34 & 280 & $0.19 / 0.19$ \\
$(S)-\mathbf{2 6}$ & 7.3 & 6.8 & 4.0 & 28 & 230 & $0.20 / 0.20$ \\
$(S)-\mathbf{2 7}$ & 30 & 1.5 & 1.6 & 0 & 0 & $0.20 / 0.20$
\end{tabular}

${ }^{\mathrm{a}}$ Compounds were dosed in dog in an $\mathrm{N}$-in-1 format. Vehicle for both iv and po: $70 \%$ water; $10 \%$ ethanol; $10 \%$ dimethylacetamide: $10 \%$ polypropylene glycol. ${ }^{\mathrm{b}}$ Compound dosed in dog in a discrete format. PO dose: $1 \mathrm{mpk}$. PO vehicle: $70 \%$ PEG400; 20\% TPGS; $10 \%$ ethanol.

\subsection{Serine Protease Selectivity.}

The serine protease selectivity profiles for the amino indazole $(S)$-2, hydroxy indazole $(S)$-10, and the methyl $N$-phenyl carbamate $(S)$-17 containing the basic cyclohexyl methyl amine $\mathrm{P} 1$ are listed in Table 7. Compound $(S)-\mathbf{2 4}$, possessing methyl $N$ phenyl carbamate $\mathrm{P} 2$ prime and $p$-chlorophenyltetrazole $\mathrm{P} 1$, was also included. Compounds $(S)-2$ and $(S)-17$, possessing a basic P1 group, showed $>1,000$-fold selectivity against many of the relevant serine proteases, except for plasma kallikrein $(<7$-fold) and trypsin $(<16$-fold). Interestingly, the hydroxy indazole $(S)$ 10 showed improved selectivity for both plasma kallikrein $(>140$ fold) and trypsin (>250-fold). ${ }^{27}$ Replacing the cyclohexyl methyl amine P1 in $(S)-\mathbf{1 7}$ with the $p$-chlorophenyltetrazole P1 in $(S)-24$ also led to an improvement in selectivity for both plasma kallikrein (80-fold) and trypsin (>270-fold). ${ }^{28}$ 
Scheme 1. Synthesis of 4-chloropyridine $1 \mathrm{c} /(S)-\mathbf{1 c}$ and boronate $\mathbf{1 g}{ }^{\mathrm{a}}$

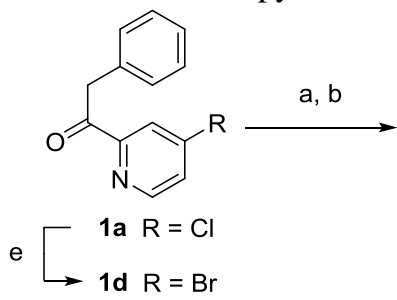<smiles>[R]c1ccnc(C(N)Cc2ccccc2)c1</smiles><smiles>[R]c1ccnc(C(Cc2ccccc2)NC(=O)C2CCC(CNC(=O)OCc3ccccc3)CC2)c1</smiles>

1b $\mathrm{R}=\mathrm{Cl}$

1e $\mathrm{R}=\mathrm{Br}$

d

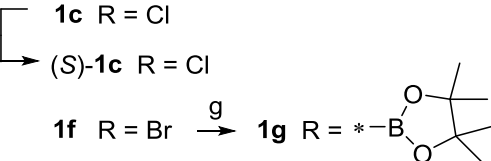

${ }^{a}$ Reagents and conditions: (a) hydroxylamine hydrochloride, $\mathrm{MeOH}$; (b), Zn, TFA, $0{ }^{\circ} \mathrm{C}, 74-98 \%$ over two steps; (c) Boc-tranexamic acid, EDC, HOBt, Hunig's base, DMF, rt, $66 \%$; (d) chiral prep HPLC; (e) TMSBr, propionitrile, microwave $150^{\circ} \mathrm{C}, 64 \%$; (f) Boc-tranexamic acid, BOP reagent, Et $3 \mathrm{~N}, \mathrm{DMF}$, rt, $84 \%$; (g) $\mathrm{Pd}(\mathrm{dppf}) \mathrm{Cl}_{2} \cdot \mathrm{CH}_{2} \mathrm{Cl}_{2}$, bis(pinacolato)diboron, $\mathrm{KOAc}$, dioxane, $80{ }^{\circ} \mathrm{C}, 4 \mathrm{~h}, 60 \%$.

Scheme 2. Synthesis of compounds with bicyclic P2 prime groups from 4-chloropyridine 1c or $(S)-\mathbf{1 c}{ }^{\text {a }}$

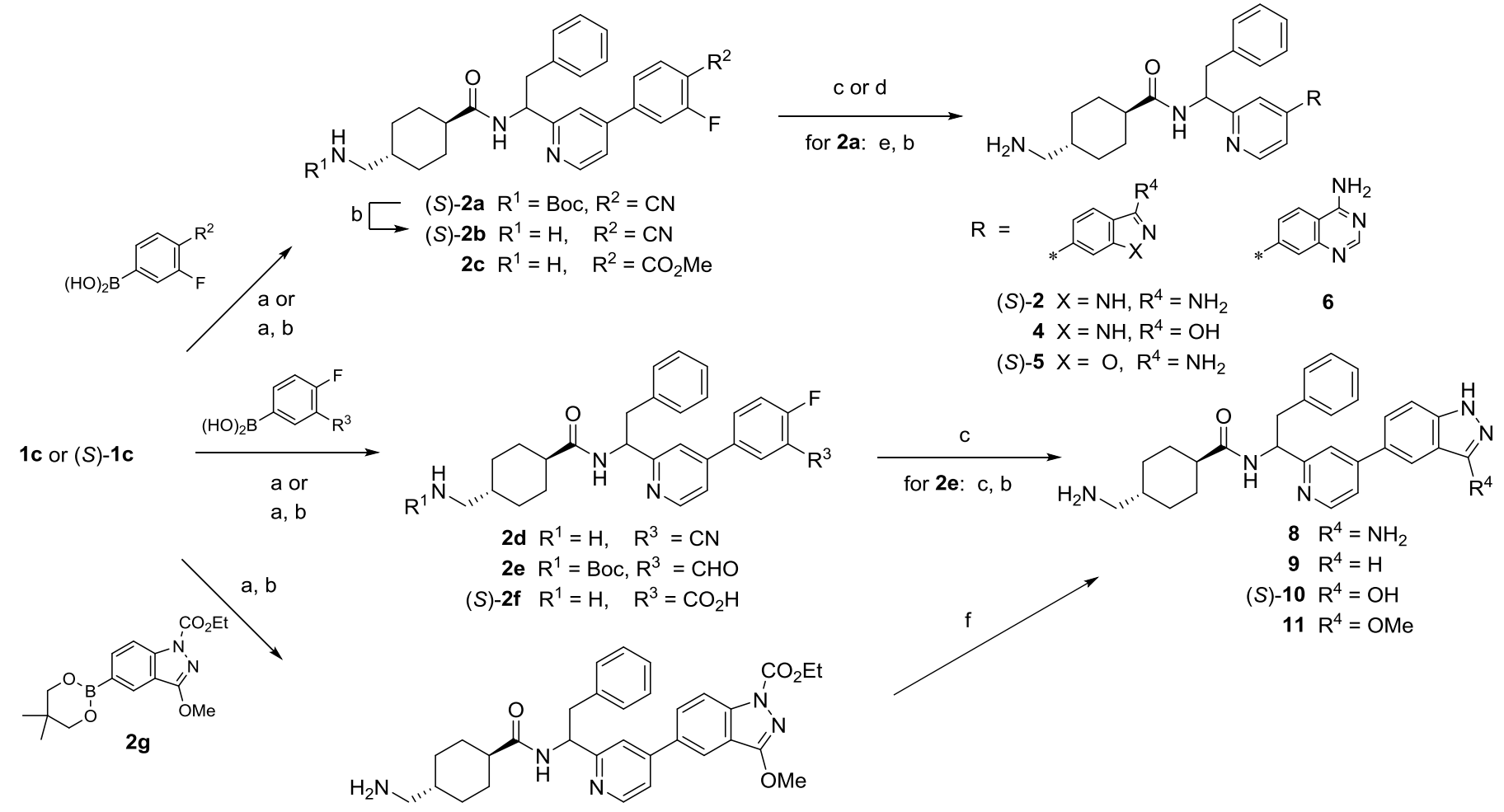

$2 \mathrm{~h}$

${ }^{a}$ Reagents and conditions: (a) Aryl boronic acid/ester, $\mathrm{Pd}_{2}(\mathrm{dba})_{3}, \mathrm{tBu}_{3} \mathrm{PHBF}_{4}, \mathrm{Cs}_{2} \mathrm{CO}_{3}$, dioxane, $90{ }^{\circ} \mathrm{C}$; or $\mathrm{Pd}\left(\mathrm{dppf} \mathrm{Cl}_{2} \cdot \mathrm{CH}_{2} \mathrm{Cl}_{2}, \mathrm{~K}_{3} \mathrm{PO}\right.$, $\mathrm{DMSO}, 90{ }^{\circ} \mathrm{C}$; (b) $30-$ $50 \%$ TFA (v/v), $\mathrm{CH}_{2} \mathrm{Cl}_{2}, \mathrm{rt}, 11-73 \%$ over two steps; (c) hydrazine monohydrate, $\mathrm{nBuOH}$, microwave, $160{ }^{\circ} \mathrm{C}, 16-71 \%$; (d) acetohydroxamic acid, $\mathrm{KOtBu}, \mathrm{DMF}$, $43 \%$; (e) formamidine acetate, DMA, $120{ }^{\circ} \mathrm{C}, 11 \%$; (f) $\mathrm{NaOH}, \mathrm{MeOH}, \mathrm{rt}, 75 \%$.

Scheme 3. Synthesis of compounds with bicyclic P2 prime groups from boronate 1g. ${ }^{\text {a }}$<smiles>[R]c1ccnc(C(Cc2ccccc2)NC(=O)C2CCCCC2)c1</smiles><smiles>[R]c1ccnc(C(Cc2ccccc2)NC(=O)C2CCC(CN)CC2)c1</smiles>

${ }^{a}$ Reagents and conditions: (a) Aryl bromide, $\mathrm{Pd}_{2}(\mathrm{dba})_{3}, \mathrm{tBu}_{3} \mathrm{PHBF}_{4}, \mathrm{Cs}_{2} \mathrm{CO}_{3}$, dioxane, $90{ }^{\circ} \mathrm{C}$; (b) $30 \% \mathrm{TFA}$ (v/v), $\mathrm{CH}_{2} \mathrm{Cl}_{2}$, rt, 29-34\% over two steps; (c) $\mathrm{Pd}(\mathrm{OAc})_{2}, \mathrm{BINAP}, \mathrm{Cs}_{2} \mathrm{CO}_{3}$, benzophenone imine, DMSO, $85^{\circ} \mathrm{C}$; (d) $30 \% \mathrm{TFA}(\mathrm{v} / \mathrm{v}), \mathrm{CH}_{2} \mathrm{Cl}$, rt; (e) $4 \mathrm{M} \mathrm{HCl}$ in dioxane, water, $9 \%$ over three step 
Table 7. Human Serine Protease Selectivity Profile for $(S)$-2, $(S)-\mathbf{1 0},(S)-\mathbf{1 7}$, and $(S)-\mathbf{2 4}$.

\begin{tabular}{lrrrr}
\hline $\begin{array}{l}\text { Human Enzyme Ki } \\
(\mathbf{n M})^{a}\end{array}$ & $(\boldsymbol{S}) \mathbf{- 2}$ & $(\boldsymbol{S}) \mathbf{- 1 0}$ & $(\boldsymbol{S}) \mathbf{- 1 7}$ & $(\boldsymbol{S}) \mathbf{- 2 4}$ \\
\hline Factor XIa & 7.2 & 3.7 & 6.3 & 23 \\
Factor VIIa & $>10,890$ & $>15,180$ & $>12,170$ & $>13,390$ \\
Factor IXa & $>34,860$ & $>34,860$ & $>34,860$ & $\mathrm{NT}$ \\
Factor Xa & $>9,000$ & $>9,000$ & $>9,000$ & 1,128 \\
Thrombin & $>12,610$ & $>12,610$ & $>12,610$ & $>13,340$ \\
Trypsin & 64 & 999 & 101 & $>6218$ \\
Plasma Kallikrein & 24 & 550 & 42 & 1,850 \\
Activated Protein C & $>21,400$ & $>30,220$ & $>30,220$ & $>30,220$ \\
Plasmin & $>22,100$ & $>22,100$ & $>22,100$ & 12,540 \\
TPA & $>21,900$ & $>21,900$ & $>21,900$ & 10,500 \\
Urokinase & $>14,060$ & $>14,060$ & $>14,060$ & $>29,730$ \\
Chymotrypsin & $>20,780$ & $>20,780$ & $>20,780$ & 29,540 \\
\hline aAll K values in
\end{tabular}

${ }^{\mathrm{a}} \mathrm{All} \mathrm{K}_{\mathrm{i}}$ values in $\mathrm{nM}$ were obtained using human purified enzymes.

\subsection{Chemistry}

The synthesis of 4-chloropyridine 1c, $(S)$-1c, and boronate $\mathbf{1 g}$, key intermediates needed for the exploration of the $\mathrm{S} 2$ prime pocket, are described in Scheme 1. Condensation of ketone 1a with hydroxylamine hydrochloride generated the oxime and subsequent reduction with zinc dust and TFA, according to the procedure of Negi, provided amine $\mathbf{1 b}{ }^{29}$ Amide coupling of amine 1b with Boc-tranexamic acid gave 1c. The enantiomers of 1c were separated by chiral preparatory HPLC to give $(S)-\mathbf{1 c} .^{30}$ Efforts to convert 4-chloropyridine 1c to boronate 1g were not successful, so 4-bromopyridine derivative 1f was prepared. Using a modification of the procedure described by Schlosser, ketone 1a was treated with trimethylsilyl bromide in propionitrile at elevated temperature in a microwave to give the 4bromopyridine 1d. ${ }^{31}$ Compound $1 \mathbf{d}$ was then converted to 1 f according to the sequence described for 1c. Miyaura borylation on 1 f afforded boronate 1g. With the key intermediates in hand, exploration of the $\mathrm{S} 2$ prime pocket was initiated.

The synthesis of analogues 2, 4-6, and 8-11 are described in Scheme 2. Suzuki-Miyaura coupling of 1c or $(S)$-1c with a variety of aryl boronic acids or esters, followed by Bocdeprotection with TFA in DCM gave compounds $\mathbf{2 b - 2 d}, \mathbf{2 f}$, and $\mathbf{2 h}$. Heating $\mathbf{2 b}$ and $\mathbf{2 d}$ with hydrazine monohydrate in n-butanol at $160^{\circ} \mathrm{C}$ in a microwave provided amino indazole derivatives 2 and $\mathbf{8}$. Similarly, heating $\mathbf{2 c}$ and $\mathbf{2 f}$ with hydrazine monohydrate in n-butanol at elevated temperatures afforded hydroxy indazole derivatives 4 and 10. Amino benzisoxazole 5 was prepared by reacting $\mathbf{2 b}$ with the potassium salt of $\mathrm{N}$-hydroxyacetamide according to the procedure described by Palermo. ${ }^{32}$ Heating $2 \mathbf{a}$ with formamidine acetate in DMAC at $120^{\circ} \mathrm{C}$ afforded, after Boc-deprotection, 4-aminoquinazoline 6. Indazole 9 was prepared in a two-step sequence by heating $\mathbf{2 e}$ with hydrazine monohydrate at elevated temperatures following Bocdeprotection. Hydrolysis of the ethyl carbamate on $\mathbf{2 h}$ with $\mathrm{NaOH}$ at room temperature yielded 3-OMe indazole $\mathbf{1 1}$.

Analogues 3, 7, and 12 were prepared according to Scheme 3. Suzuki-Miyaura coupling of boronate $\mathbf{1 g}$ with appropriately substituted arylbromides, 3a-3c, provided 3d-3f. Compounds 3d and $\mathbf{3 f}$ were deprotected with TFA in DCM to give $\mathbf{3}$ and $\mathbf{1 2}$, respectively. Compound $\mathbf{3 e}$ was converted to 1-amino isoquinoline 7 in a three step sequence, specifically Buchwald-
Hartwig amination of $\mathbf{3 e}$ with benzophenone imine, Bocdeprotection and then hydrolysis of the imine.

The synthesis of the monocyclic P2 prime analogues 13-17 are described in Scheme 4. Suzuki-Miyaura coupling of 1c or $(S)-\mathbf{1 c}$ with a variety of aryl- and heteroarylboronic acids gave compounds 4a, 4c-4e, and (S)-4f. Methyl ester 4a was hydrolyzed to the anthranilic acid $\mathbf{4 b}$ with $\mathrm{NaOH}$ in $\mathrm{MeOH}$ at 60 ${ }^{\circ} \mathrm{C}$ and then deprotection with TFA in DCM provided 13. Compounds $\mathbf{4 c}, \mathbf{4 d}, \mathbf{4 e}$, and $(S)-\mathbf{4 f}$ were deprotected with TFA in DCM to give $\mathbf{4 g}, \mathbf{1 5}, \mathbf{4 h}$, and $(S)-\mathbf{1 7}$, respectively. Saponification of methyl ester $\mathbf{4 g}$ yielded carboxylic acid $\mathbf{1 4}$. Nucleophilic aromatic substitution of fluoro pyridine $\mathbf{4 h}$ with ammonium hydroxide at $140^{\circ} \mathrm{C}$ in a microwave gave amino pyridine $\mathbf{1 6}$.

Scheme 5 describes the syntheses of the phenyl and regioisomeric pyridine scaffolds. Condensation of 3bromobenzaldehdye with lithium bis(trimethylsilyl)amide generates the $\mathrm{N}$-trimethylsilylaldimine, followed by the addition of benzyl magnesium bromide according to the procedure of Hart, gave after aqueous work up, the primary amine 5a. ${ }^{33}$ The enantiomers were separated by chiral preparatory HPLC which provided $(S)-5 \mathbf{a}^{30}$ Amide coupling of amine $(S)-5 \mathbf{a}$ with Boctranexamic acid, followed by Suzuki-Miyaura coupling with 4(methoxycarbonylamino)phenylboronic acid and Bocdeprotection afforded (S)-18. Analogs containing the regioisomeric pyridine scaffolds were prepared via a different sequence. Negishi coupling of acid chlorides $\mathbf{5 c}$ and $\mathbf{5 g}$ with benzyl zinc chloride in the presence of $\mathrm{Pd}\left(\mathrm{PPh}_{3}\right)_{4}$ afforded ketones $\mathbf{5 d}$ and $\mathbf{5 h}$. The ketones $\mathbf{5 d}$ and $\mathbf{5 h}$ were converted to their corresponding amides $(S)-\mathbf{5 f}$ and $(S)-\mathbf{5} \mathbf{j}$ according to the sequence previously described in Scheme 1. Suzuki-Miyaura coupling of amides $(S)-\mathbf{5 f}$ and $(S) \mathbf{- 5} \mathbf{j}$ with 4(methoxycarbonylamino)phenylboronic acid, followed by Bocdeprotection, afforded $(S)$-19 and $(S)$-20.

Scheme 6 describes the synthesis of the pyrimidine scaffold. Condensation of the $\beta$-ketoester $\mathbf{6 a}$, prepared according to a modified procedure of Maibaum, with formamidine acetate in the presence of $\mathrm{NaOMe}$ gave pyrimidinone $\mathbf{6 b} .^{34,35}$ Heating pyrimidinone $\mathbf{6} \mathbf{b}$ and $\mathrm{POCl}_{3}$ leads to the formation of the chloro pyrimidine as well as the deprotection of the Boc group. The amine was reprotected with Boc-anhydride to yield 6c. SuzukiMiyaura coupling with 4-(methoxycarbonylamino)phenylboronic acid and Boc-deprotection afforded amine 6d. The enantiomers were separated by chiral preparatory HPLC which provided $(S)$ 6d. Amide coupling with Boc-tranexamic acid and then Bocdeprotection gave $(S)$-21

Scheme 7 describes the synthesis of $(S)$-24 to $(S)$-26 analogs which contain the neutral $p$-chlorophenyltetrazole P1. SuzukiMiyaura coupling of $(S)$-7a with 4(methoxycarbonylamino)phenylboronic acid followed by Bocdeprotection afforded amine $(S)-7 \mathbf{b}$. Amide coupling of amine $(S)-\mathbf{7 b}$ with the activated cinnamic ester 7d yielded $(S)$-24. The regioisomeric pyridine scaffold was prepared via a different method than previously described in Scheme 5. Condensation of aldehyde 7e, with (R)-2-methylpropane-2-sulfinamide in the presence of $\mathrm{Ti}(\mathrm{OEt})_{4}$ gave the corresponding sulfinimine which was reacted with benzylmagnesium chloride to give diastereomeric sulfinamides $(R, S)$-7f and $(R, S)$-7f, which are separable by normal phase chromatography. ${ }^{36}$ Suzuki-Miyaura coupling of $(R, S)$-7f with 4(methoxycarbonylamino)phenylboronic acid and removal of the chiral auxiliary afforded amine $(S)-7$ g. Amide coupling of amine $(S)-7 \mathbf{g}$ with cinnamic acid 7c provided $(S)-25$. The pyrimidine analog $(S)$-26 was prepared by coupling amine $(S)$-6d with the activated cinnamic ester $\mathbf{7 d}$.

The synthesis of the pyridinone derivatives $(S)-22$ and $(S)-27$ is described in Scheme 8. Horner-Wadsworth-Emmons 
Scheme 4. Synthesis of compounds with monocyclic P2 prime groups from 4-chloropyridine $1 \mathbf{c}$ or $(S)-\mathbf{1 c}{ }^{\mathrm{a}}{ }^{\mathrm{a}}$<smiles>[R]c1cc(-c2ccnc(C(Cc3ccccc3)NC(=O)C3CCC(CNC(=O)OCc4ccccc4)CC3)c2)cc([R])c1[R]</smiles><smiles>[R]c1cc(-c2ccnc(C(Cc3ccccc3)NC(=O)C3CCC(CN)CC3)c2)cc([R])c1[R]</smiles>

b $-4 a \quad X=C H, R^{1}=\mathrm{NH}_{2}, \mathrm{R}^{2}=\mathrm{CO}_{2} \mathrm{Me}$

4b $X=C H, R^{1}=\mathrm{NH}_{2}, \mathrm{R}^{2}=\mathrm{CO}_{2} \mathrm{H}$

4c $X=\mathrm{CH}, \mathrm{R}^{1}=\mathrm{H}, \quad \mathrm{R}^{2}=\mathrm{CO}_{2} \mathrm{Me}$

4d $X=C H, R^{1}=$ NHBoc, $R^{2}=H$

4e $X=N, R^{1}=F, R^{2}=H$

(S)-4f $\mathrm{X}=\mathrm{CH}, \mathrm{R}^{1}=\mathrm{NHCO}_{2} \mathrm{Me}, \mathrm{R}^{2}=\mathrm{H}$

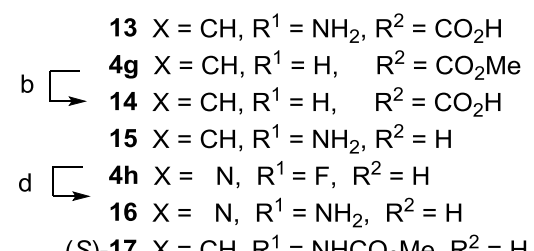

(S) $-17 X=\mathrm{CH}, \mathrm{R}^{1}=\mathrm{NHCO}_{2} \mathrm{Me}, \mathrm{R}^{2}=\mathrm{H}$

${ }^{a}$ Reagents and conditions: (a) Aryl- or heteroarylboronic acid, $\mathrm{Pd}_{2}(\mathrm{dba})_{3}, \mathrm{tBu}_{3} \mathrm{PHBF}_{4}, \mathrm{Cs}_{2} \mathrm{CO}_{3}$, dioxane, $90{ }^{\circ} \mathrm{C}, 78-88 \%$; (b) $\mathrm{NaOH}, \mathrm{MeOH}, 60{ }^{\circ} \mathrm{C}$; (c) $30 \%$ TFA (v/v), $\mathrm{CH}_{2} \mathrm{Cl}_{2}, \mathrm{rt}, 6-87 \%$ over two steps; (d) ammonium hydroxide, $140{ }^{\circ} \mathrm{C}$, microwave, $41 \%$.

Scheme 5. Synthesis of compounds containing phenyl $(S)$-18 and regioisomeric pyridine $(S)-\mathbf{1 9}$ and $(S)$-20 scaffolds. ${ }^{\text {a }}$

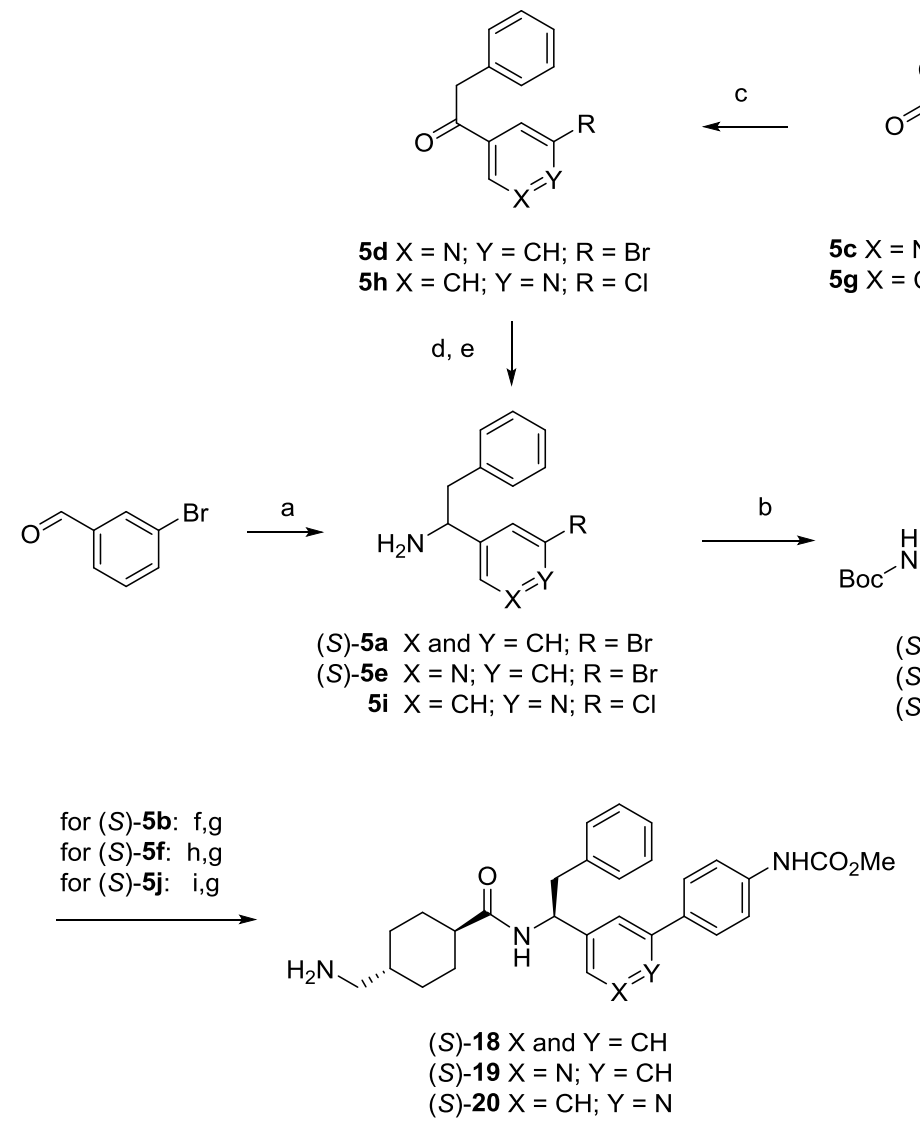

${ }^{a}$ Reagents and conditions: (a) LiHMDS, THF, $0{ }^{\circ} \mathrm{C}$, then $\mathrm{BnMgCl}, 80 \%$, then chiral prep HPLC; (b) Boc-tranexamic acid, EDC, HOBt, Hunig's base, DMF, rt, 47-84\%, for 5j chiral prep HPLC; (c) $\mathrm{Pd}\left(\mathrm{Ph}_{3} \mathrm{P}\right){ }_{4}, \mathrm{BnZnCl}, \mathrm{THF},-30{ }^{\circ} \mathrm{C}$ to $0{ }^{\circ} \mathrm{C}, 45-64 \%$; (d) hydroxylamine hydrochloride, $\mathrm{MeOH}$; $(\mathrm{e}), \mathrm{Zn}, \mathrm{TFA}, 0{ }^{\circ} \mathrm{C}, 35-50 \%$ over two steps, for 5e chiral prep HPLC; (f) 4-(methoxycarbonylamino)phenylboronic acid, $\left.\mathrm{Pd}_{\left(\mathrm{Ph}_{3} \mathrm{P}\right)}\right)_{4}, \mathrm{DME}, \mathrm{water}, 60{ }^{\circ} \mathrm{C}$; $(\mathrm{g}) 30 \%$ TFA $(\mathrm{v} / \mathrm{v}), \mathrm{CH}{ }_{2} \mathrm{Cl}{ }_{2}, \mathrm{rt}, 34-$ $71 \%$ over two steps; (h) 4-(methoxycarbonylamino)phenylboronic acid, $\mathrm{Pd}(\mathrm{dppf}) \mathrm{Cl}_{2} \cdot \mathrm{CH}_{2} \mathrm{Cl}_{2}, \mathrm{~K}_{3} \mathrm{PO}_{4}$, DMSO, $90{ }^{\circ} \mathrm{C}$; (i) $4-($ methoxycarbonylamino)phenyl boronic acid, $\mathrm{Pd}_{2}(\mathrm{dba})_{3}, \mathrm{tBu}_{3} \mathrm{PHBF}_{4}, \mathrm{Cs}_{2} \mathrm{CO}_{3}$, dioxane, $90^{\circ} \mathrm{C}$. 
reaction of $\beta$-ketophosphonate $(S)-\mathbf{8} \mathbf{a}^{37}$ and 4-nitrobenzaldehyde gave the corresponding $\alpha, \beta$-unsaturated ketone which was condensed with 1-(ethoxycarbonylmethyl)-pyridinium chloride in the presence of ammonium acetate in $\mathrm{EtOH}$ at elevated temperature to give scalemic pyridinone $\mathbf{8 b}{ }^{38}$ The nitro group was reduced to the aniline and then reacted with methyl chloroformate to give, following mild hydrolysis with sodium hydroxide, carbamate 8c. After removing the Boc group, the scalemic amine was purified by chiral preparatory hplc to give $(S)-8 d$. Amine $(S)-8 d$ was coupled with Boc-tranexamic acid and then deprotection of the Boc-group gave $(S)$-22. Amine $(S)$-8d was coupled with cinnamic acid 7c which provided $(S)-\mathbf{2 7}$.

\section{Conclusions}

Pyridine-based FXIa inhibitor $(S)$-2 was optimized by modifying the P2 prime, $\mathrm{P} 1$ and scaffold regions. Exploration of the $\mathrm{P} 2$ prime region identified 3-amino benzisoxazole, 3-hydroxy indazole, anthranilic acid, and methyl $\mathrm{N}$-phenyl carbamate groups as potent replacements for 3 -amino indazole. The methyl $\mathrm{N}$ phenyl carbamate, found in $(S)-\mathbf{1 7}$, became the preferred P2 prime moiety since it not only maintained FXIa activity but improved oral exposure in dog even with the basic cyclohexyl methyl amine P1. Moreover, replacing the basic cyclohexyl methyl amine P1 with neutral $p$-chlorophenyltetrazole P1 resulted in the discovery of $(S)-\mathbf{2 4}$, which showed a significant improvement in oral bioavailability in dog compared to the previously reported imidazole analog (S)-23. Additional improvements in FXIa binding affinity, while maintaining oral bioavailability, was achieved with regioisomeric pyridine $(S)-\mathbf{2 5}$ and pyrimidine $(S)$-26. Further efforts to improve both FXIa potency and pharmacokinetics will be reported in due course.

\section{Experimental section}

\subsection{Chemistry}

All reactions were run under and atmosphere of dry nitrogen or argon unless otherwise noted. Solvents and reagents were obtained from commercial vendors in the appropriate grade and used without further purification unless otherwise indicated. Proton, carbon, and fluorine magnetic resonance $\left({ }^{1} \mathrm{H},{ }^{13} \mathrm{C}\right.$, and ${ }^{19} \mathrm{~F}$ NMR) spectra were recorded either on a Bruker Avance 400, JEOL Eclipse 400, or a JEOL Eclipse 500 spectrometer. Chemical shifts are given in parts per million (ppm) relative to either the reference solvent of the sample in which they were run or tetramethylsilane (TMS). HPLC analyses of all final compounds were performed using the following conditions: Zorbax SB C18 $4.6 \mathrm{~mm} \times 75 \mathrm{~mm}$ column with a binary solvent system where solvent $\mathrm{A}=10 \%$ methanol, $90 \%$ water, $0.2 \%$ phosphoric acid, and solvent $\mathrm{B}=90 \%$ methanol, $10 \%$ water, $0.2 \%$ phosphoric acid, flow rate $=2.5 \mathrm{~mL} / \mathrm{min}$, linear gradient time $=8 \mathrm{~min}$, start $\% \mathrm{~B}=0$, final $\% \mathrm{~B}=100$, detection $220 \mathrm{~nm}$. All final compounds had an HPLC purity of $\geq 95 \%$ unless specifically mentioned. High resolution mass spectra were measured on an Agilent TOF 6210 LC/MS system with electrospray ionization (ESI). LCMS analyses were recorded on a Shimadzu LC-10AT equipped with a SIL-10A injector, a SPD$10 \mathrm{AV}$ detector normally operating at $220 \mathrm{~nm}$, and interfaced with a Micromass ZMD mass spectrometer. LCMS analyses used the following conditions: Phenomenex Luna $5 \mu \mathrm{m} \mathrm{C18} 4.6 \mathrm{~mm} \times 50$ $\mathrm{mm}$ column with a binary solvent system where solvent $\mathrm{A}=10 \%$ methanol, $90 \%$ water, $0.1 \%$ trifluoroacetic acid, and solvent $\mathrm{B}=$ $90 \%$ methanol, $10 \%$ water, $0.1 \%$ trifluoroacetic acid, flow rate $=$ $4 \mathrm{~mL} / \mathrm{min}$, linear gradient time $=4 \mathrm{~min}$, start $\% \mathrm{~B}=0$, final $\% \mathrm{~B}=$ 100. Elemental analyses were performed by Robertson Microlit Laboratories, Inc., Ledgewood, NJ 07852 and were within $0.4 \%$ of the theoretical values. Flash chromatography was performed using EM Science silica gel 60 (230-400 mesh). Preparative reverse-phase HPLC purifications were performed using the following conditions: a binary solvent system where solvent $\mathrm{A}=$ $10 \%$ methanol, $90 \%$ water, $0.1 \%$ trifluoroacetic acid, and solvent $\mathrm{B}=90 \%$ methanol, $10 \%$ water, $0.1 \%$ trifluoroacetic acid, detector $220 \mathrm{~nm}$. The enantiomers were separated by chiral preparatory HPLC and the conditions indicated in the corresponding experimental procedure. Optical rotations were performed on a Jasco P-1010 polarimeter.

\subsubsection{1-(4-Chloropyridin-2-yl)-2-phenylethan-1-one (1a).}

To a cooled $\left(-40 \quad{ }^{\circ} \mathrm{C}\right)$ solution of methyl 4-chloropyridine-2-carboxylate $(14.5 \mathrm{~g}, 84.5 \mathrm{mmol})$ in THF $(192 \mathrm{~mL})$ was added rapidly via cannula a cooled $\left(-40^{\circ} \mathrm{C}\right)$, pale brown solution of 0.6 M benzylmagnesium chloride in THF (142 mL, 84.5 mmol). The resulting, clear orange solution was stirred at $-40{ }^{\circ} \mathrm{C}$. After $1 \mathrm{~h}$ the reaction was quenched with glacial acetic acid (5.4 $\mathrm{mL}, 93 \mathrm{mmol}$ ) and the reaction was warmed to $\mathrm{rt}$. The reaction was partitioned between EtOAc and sat. $\mathrm{NaHCO}_{3}$ and the layers were separated. The aqueous layer was extracted with EtOAc (3x). The organic layers were combined and washed with brine, dried over $\mathrm{Na}_{2} \mathrm{SO}_{4}$, filtered, and concentrated to give a red-brown liquid weighing $21.6 \mathrm{~g}$. Column chromatography on silica gel (1.5:1 DCM:Hex) gave $10.1 \mathrm{~g}$ (52\% yield) of $1 \mathrm{a}$ as an orange liquid. LCMS: $232.1(\mathrm{M}+\mathrm{H})^{+}$and $234.0(\mathrm{M}+2+\mathrm{H})^{+} .{ }^{1} \mathrm{H} \mathrm{NMR}$ $\left(500 \mathrm{MHz}, \mathrm{CDCl}_{3}\right) \delta: 8.63(\mathrm{~d}, J=5.5 \mathrm{~Hz}, 1 \mathrm{H}), 8.03(\mathrm{~d}, J=2.2$ $\mathrm{Hz}, 1 \mathrm{H}), 7.46$ (dd, $J=5.0,2.2 \mathrm{~Hz}, 1 \mathrm{H}), 7.34-7.28$ (m, 4H), 7.27$7.22(\mathrm{~m}, 1 \mathrm{H}), 4.52(\mathrm{~s}, 2 \mathrm{H}) .{ }^{13} \mathrm{C} \mathrm{NMR}\left(125 \mathrm{MHz}, \mathrm{CDCl}_{3}\right) \delta$ : $197.9,154.2,149.8,145.5,134.2,129.9,128.5,127.2,126.8$, $122.8,44.1$.

\subsubsection{1-(4-Chloropyridin-2-yl)-2-phenylethan-1-amine (1b).}

Compound $1 \mathrm{~b}$ was prepared following a modified procedure of Negi. ${ }^{29}$ To a clear, yellow solution of $\mathbf{1 a}(3.96 \mathrm{~g}, 17.1 \mathrm{mmol})$ in $\mathrm{MeOH}(34 \mathrm{~mL})$ was added hydroxylamine hydrochloride $(3.56 \mathrm{~g}$, $51.3 \mathrm{mmol})$. The resulting suspension was stirred at rt. After 14 $\mathrm{h}$ the reaction was concentrated to give a yellow solid. The solid was dissolved in EtOAc and washed with sat. $\mathrm{NaHCO}_{3}$. The layers were separated and the aqueous layer was extracted with EtOAc. The organic layers were combined and washed with brine, dried over $\mathrm{Na}_{2} \mathrm{SO}_{4}$, filtered, and concentrated to give 4.13 $\mathrm{g}$ of the corresponding oxime as a pink solid. LCMS: 247.1 $(\mathrm{M}+\mathrm{H})^{+}$and $249.1(\mathrm{M}+2+\mathrm{H})^{+}$

To a cooled $\left(5^{\circ} \mathrm{C}\right)$, clear, yellow solution of oxime $(4.13 \mathrm{~g})$ in TFA $(39.5 \mathrm{~mL})$ was added in portions zinc dust $(11.18 \mathrm{~g}, 171$ mmol) so as to keep the temperature below $25^{\circ} \mathrm{C}$. After $1.5 \mathrm{~h}$, the reaction was filtered through a cotton plug, rinsing with TFA $(50 \mathrm{~mL})$. The filtrate was poured slowly into a cold $\left(0{ }^{\circ} \mathrm{C}\right)$, vigorously stirred suspension of $2 \mathrm{M} \mathrm{NaOH}(700 \mathrm{~mL})$ and DCM $(500 \mathrm{~mL})$. The layers were separated and the aqueous layer was extracted with DCM. The combined organic layers were washed with brine, dried over $\mathrm{MgSO}_{4}$, filtered and concentrated to give $3.64 \mathrm{~g}$ as a clear, orange-brown liquid. Column chromatography on silica gel $(5 \% \mathrm{MeOH}$ in DCM with $0.5 \%$ ammonium hydroxide) gave $2.93 \mathrm{~g}$ (74\% yield over two steps) of $\mathbf{1 b}$ as a clear, yellow oil. LCMS: $233.1(\mathrm{M}+\mathrm{H})^{+}$and $235.1(\mathrm{M}+2+\mathrm{H})^{+}$. ${ }^{1} \mathrm{H}$ NMR $\left(500 \mathrm{MHz}, \mathrm{CDCl}_{3}\right) \quad \delta: 8.47(\mathrm{~d}, J=5.0 \mathrm{~Hz}, 1 \mathrm{H}), 7.31-$ $7.25(\mathrm{~m}, 3 \mathrm{H}), 7.23-7.20(\mathrm{~m}, 1 \mathrm{H}), 7.17-7.14(\mathrm{~m}, 3 \mathrm{H}), 4.21(\mathrm{dd}, J=$ $8.8,5.5 \mathrm{~Hz}, 1 \mathrm{H}), 3.15(\mathrm{dd}, J=13.8,5.0 \mathrm{~Hz}, 1 \mathrm{H}), 2.82(\mathrm{dd}, J=$ $13.8,8.8 \mathrm{~Hz}, 1 \mathrm{H}), 1.60(\mathrm{bs}, 2 \mathrm{H}) .{ }^{13} \mathrm{C} \mathrm{NMR}\left(125 \mathrm{MHz}, \mathrm{CDCl}_{3}\right) \delta$ : $165.9,150.1,144.5,138.4,129.3,128.5,126.6,122.4,121.6$, 58.5, 45.1. 
Scheme 6. Synthesis of pyrimidine $(S)$-21 scaffold. ${ }^{\text {a }}$<smiles>COC(=O)CC(=O)C(Cc1ccccc1)NC(=O)C(C)(C)C</smiles><smiles>CCOC(=O)Nc1ccc(-c2cc(C(N)Cc3ccccc3)ncn2)cc1</smiles>

$(S)-21$

${ }^{\mathrm{a}}$ Reagents and conditions: (a) formamidine acetate, $\mathrm{NaOMe}, \mathrm{MeOH}, 58 \%$; (b) $\mathrm{POCl}_{3}, 50^{\circ} \mathrm{C}$; (c) $\mathrm{Boc}_{2} \mathrm{O}, \mathrm{Et}_{3} \mathrm{~N}$, DCM, $28 \%$ over two steps; (d) $4-$ (methoxycarbonylamino)phenylboronic acid, $\mathrm{Pd}(\mathrm{dppf}) \mathrm{Cl}_{2} \cdot \mathrm{CH}_{2} \mathrm{Cl}_{2}, \mathrm{~K}_{3} \mathrm{PO}_{4}$, DMSO, $85{ }^{\circ} \mathrm{C}$; (e) $30 \% \mathrm{TFA}$ (v/v), $\mathrm{CH}_{2} \mathrm{Cl}_{2}$, rt, $37-46 \%$ over two steps; (f) chiral prep HPLC; (g) Boc-tranexamic acid, EDC, HOBt, Hunig's base, DMF.

Scheme 7. Synthesis of compounds $(S)$-24 to $(S)$-26 containing the neutral $p$-chlorophenyl tetrazole P1. ${ }^{\text {a }}$<smiles>CC(C)(C)OC(=O)NC(Cc1ccccc1)c1cc(Cl)ccn1</smiles>

$(S)-7 \mathbf{a}$<smiles>[Y]c1cc(Cc2ccccc2)cc(-c2ccc(NC(C)=O)cc2)c1</smiles>

(S)-7b $X=\mathrm{N} ; \mathrm{Y}=\mathrm{CH} ; \mathrm{Z}=\mathrm{CH}$

(S)-7g X $=\mathrm{CH} ; \mathrm{Y}=\mathrm{CH} ; \mathrm{Z}=\mathrm{N}$

(S) $-6 \mathbf{d} X=\mathrm{N} ; Y=\mathrm{CH} ; Z=\mathrm{N}$<smiles>[Y][C]([C](Cc1ccccc1)NC(=O)/C=C/c1cc(Cl)ccc1-n1cnnn1)c1ccc(NC(C)=O)c([Y])c1</smiles>

(S)-25 X $=\mathrm{CH} ; \mathrm{Y}=\mathrm{CH} ; \mathrm{Z}=\mathrm{N}$

(S) $-26 \quad X=N ; Y=C H ; Z=N$

a, $g \uparrow$<smiles>CC(C)(C)S(=O)N[C@H](Cc1ccccc1)c1ccnc(Br)c1</smiles>

$(R, S)-7 f$

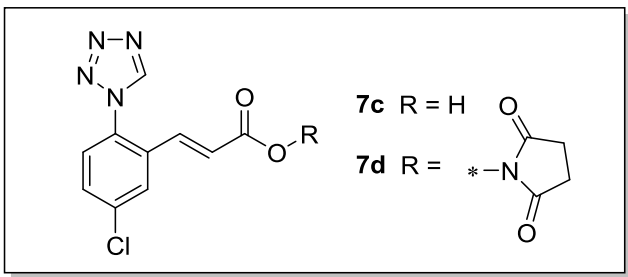

${ }^{a}$ Reagents and conditions: (a) 4-(methoxycarbonylamino)phenylboronic acid, $\mathrm{Pd}_{2}(\mathrm{dba})_{3}, \mathrm{tBu}_{3} \mathrm{PHBF}_{4}, \mathrm{Cs}_{2} \mathrm{CO}_{3}$, dioxane, $90{ }^{\circ} \mathrm{C}$, 86-99\%; (b) 15-30\% TFA (v/v),

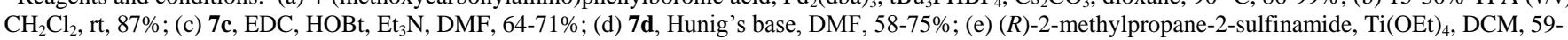
$90 \%$; (f) $1.0 \mathrm{M}$ benzylmagnesium chloride or bromide in $\mathrm{Et}_{2} \mathrm{O}, \mathrm{DCM}$; for $7 \mathbf{f}: 71 \%$ yield as a 1.4:1 mixture of diastereromers which were separated by column chromatography (g) $4 \mathrm{M} \mathrm{HCl}$ in dioxane, $\mathrm{MeOH}, 44-81 \%$.

Scheme 8. Synthesis of compounds $(S)$-22 and $(S)$-27 containing the pyridinone scaffold. ${ }^{2}$<smiles>COC(=O)N[C@@H](Cc1ccccc1)C(=O)CP(=O)(OC)OC</smiles>

$(S)-8 \mathbf{a}$<smiles>CC(C)(C)OC(=O)NC(Cc1ccccc1)c1cc(-c2ccc([N+](=O)[O-])cc2)cc(=O)[nH]1</smiles>

8b<smiles>[GeH3]</smiles><smiles>CC(=O)Nc1ccc(-c2cc(C(Cc3ccccc3)NC(C)=O)nc(=O)[nH]2)cc1</smiles><smiles>CC(=O)Nc1ccc(-c2cc(C(N)Cc3ccccc3)[nH]c(=O)c2)cc1</smiles>

$(S)-8 \mathbf{d}$

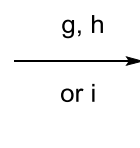<smiles>NCC1CCCC1</smiles>
$(S)-27 R=$<smiles>CC=Cc1cc(Cl)ccc1-n1cnnn1</smiles>

${ }^{a}$ Reagents and conditions: (a) 4-nitrobenzaldehyde, $\mathrm{K}_{2} \mathrm{CO}_{3}$, EtOH, rt; (b) 1-(ethoxycarbonylmethyl)-pyridinium chloride, $\mathrm{NH}_{4} \mathrm{OAc}, \mathrm{EtOH}^{\circ} 8{ }^{\circ} \mathrm{C}, 65 \%$ over two steps; (c) zinc dust, $\mathrm{NH}_{4} \mathrm{Cl}, \mathrm{MeOH}$, rt to $60{ }^{\circ} \mathrm{C}$; d) methyl chloroformate, pyridine, $\mathrm{CH}_{2} \mathrm{Cl}_{2}$; e) $\mathrm{NaOH}, \mathrm{MeOH}, 0{ }^{\circ} \mathrm{C}$; f) $50 \% \mathrm{TFA}(\mathrm{v} / \mathrm{v}), \mathrm{CH}_{2} \mathrm{Cl}_{2}, \mathrm{rt}, 35 \%$ over four steps, then chiral prep HPLC; g) Boc-tranexamic acid, BOP reagent, $\mathrm{Et}_{3} \mathrm{~N}, \mathrm{DMF}, \mathrm{rt}$; h) $50 \% \mathrm{TFA}(\mathrm{v} / \mathrm{v}), \mathrm{CH}_{2} \mathrm{Cl}_{2}$, rt, $70 \%$ over two steps; i) 7c, EDC, $\mathrm{HOBt}$, Hunig's base, DMF, $62 \%$ 
4.1.3. 2-Methyl-2-propanyl[(trans-4-\{[(1S)-1-(4-chloro-2pyridinyl)-2-phenylethyl]carbamoyl\}cyclohexyl)methyl]carbamate [(1c) and $(\mathrm{S})-1 \mathrm{c}]$.

To a cooled $\left(0{ }^{\circ} \mathrm{C}\right)$, clear, yellow solution of $\mathbf{1 b}(2.93 \mathrm{~g}, 12.6$ mmol) in DMF (42 mL) was added sequentially Boc-tranexamic acid (3.56 g, $13.8 \mathrm{mmol})$, HOBt (2.55 g, $18.8 \mathrm{mmol})$, and EDC (3.62 g, $18.8 \mathrm{mmol})$. After $15 \mathrm{~min}$. at $0{ }^{\circ} \mathrm{C}$, the reaction was warmed to rt. After $4 \mathrm{~h}$, the reaction was poured into vigorously stirred, cold $\left(0{ }^{\circ} \mathrm{C}\right)$ water $(200 \mathrm{~mL})$ to give a white suspension. Buchner funnel filtration gave a white solid which was washed with water. The white solid was dissolved in dichloromethane and washed with water, $0.5 \mathrm{M} \mathrm{HCl}$, sat. $\mathrm{NaHCO}_{3}$, brine, dried over $\mathrm{MgSO}_{4}$, filtered and concentrated to give a white solid weighing $11 \mathrm{~g}$. Column chromatography on silica gel $3: 1$ DCM:EtOAc) gave $3.91 \mathrm{~g}$ (66\% yield) of 1c as a white solid. The enantiomers were separated via chiral preparatory HPLC [Daicel Chiralcel OD column; 30\% IPA/Hex; $50 \mathrm{~mL} / \mathrm{min} ; 254$ $\mathrm{nm}]$ which gave $(R)-\mathbf{1 c}(>99 \%$ ee) as enantiomer $\mathrm{A}$ and $(S)-\mathbf{1 c}$ (>99\%ee) as enantiomer B. HRMS m/z calc'd. for $\mathrm{C}_{26} \mathrm{H}_{35} \mathrm{~N}_{3} \mathrm{O}_{3} \mathrm{Cl}$ $(\mathrm{M}+\mathrm{H})^{+}$: 472.2367. Found 472.2357. ${ }^{1} \mathrm{H}$ NMR $(500 \mathrm{MHz}$, $\left.\mathrm{CDCl}_{3}\right) \quad \delta: 8.41(\mathrm{~d}, J=5.4 \mathrm{~Hz}, 1 \mathrm{H}), 7.23-7.16(\mathrm{~m}, 4 \mathrm{H}), 6.93-$ $6.92(\mathrm{~m}, 2 \mathrm{H}), 6.89(\mathrm{~d}, J=1.3 \mathrm{~Hz}, 1 \mathrm{H}), 6.66(\mathrm{~d}, J=8.0 \mathrm{~Hz}, 1 \mathrm{H})$, $5.22(\mathrm{dd}, J=13.8,7.7 \mathrm{~Hz}, 1 \mathrm{H}), 4.58(\mathrm{bs}, 1 \mathrm{H}), 3.16(\mathrm{dd}, J=12.8$, $6.0 \mathrm{~Hz}, 1 \mathrm{H}), 3.03(\mathrm{dd}, J=13.4,7.4 \mathrm{~Hz}, 1 \mathrm{H}), 2.97-2.95(\mathrm{~m}, 2 \mathrm{H})$, 2.07-2.02 (m, 1H), 1.89-1.79 (m, 4H), 1.50-1.37 (m, 12H), 0.97$0.88(\mathrm{~m}, 2 \mathrm{H}) .{ }^{13} \mathrm{C}$ NMR $\left(125 \mathrm{MHz}, \mathrm{CDCl}_{3}\right)$ 8: 175.0, 160.9, $156.1,149.9,144.3,136.8,129.4,128.3,126.7,122.9,122.8$, 79.1, 54.7, 46.6, 45.4, 42.2, 37.7, 29.8, 29.7, 29.1, 28.8, 28.4. Anal. calc'd for $\left(\mathrm{C}_{26} \mathrm{H}_{34} \mathrm{~N}_{3} \mathrm{O}_{3} \mathrm{Cl}\right)$ : C, 66.15; H, 7.26; N, 8.90; Cl, 7.51. Found $\mathrm{C}, 65.97 ; \mathrm{H}, 7.29 ; \mathrm{N}, 8.66 ; \mathrm{Cl}, 7.54 .[\alpha]_{\mathrm{D}}{ }^{25}=-1.79$ $\left(\mathrm{c}=1.1 ; \mathrm{CHCl}_{3}\right)$.

\subsubsection{General Procedures for the Suzuki-Miyaura coupling.}

\section{Method A:}

To a flame-dried thick-walled vial was added the heteroaryl halide or aryl halide (1.0 eq), $\mathrm{Pd}_{2}(\mathrm{dba})_{3}(0.05 \mathrm{eq})$, tri-tertbutylphosphonium tetrafluoroborate $(0.12 \mathrm{eq})$, cesium carbonate (2.0 eq) and the boronic acid or ester (1.3 eq). The vial was sealed with a septum and then the vessel was purged with argon for several minutes. Next, dioxane $(0.2 \mathrm{M}$, degassed by bubbling either nitrogen or argon) was added. Under a blanket of argon, the septum was replaced with a Teflon-coated screw cap. The reaction was stirred at $\mathrm{rt}$ for $1 \mathrm{~h}$ and then the reaction was warmed to $90{ }^{\circ} \mathrm{C}$ for 12 to $24 \mathrm{~h}$ as determined by HPLC analysis of the reaction mixture. The crude product was either used without further purification or it was purified by either column chromatography on silica gel or by reverse phase chromatography.

\section{Method B:}

To a flame-dried flask was placed heteroaryl halide or aryl halide (1.0 eq.), boronic acid or ester (2.5 eq), $\mathrm{Pd}(\mathrm{dppf}) \mathrm{Cl}_{2} \cdot \mathrm{CH}_{2} \mathrm{Cl}_{2}(0.10 \mathrm{eq})$ and $\mathrm{K}_{3} \mathrm{PO}_{4}(2.5 \mathrm{eq})$. The flask was equipped with a reflux condenser and the reaction vessel was purged with argon for several minutes. Next, degassed DMSO $(0.15 \mathrm{M})$ was added and the resulting suspension was heated to $90{ }^{\circ} \mathrm{C}$. After $15 \mathrm{~h}$, the reaction was cooled to rt, diluted with DCM, washed with water, 2.0 $\mathrm{M} \mathrm{Na}_{2} \mathrm{CO}_{3}$, brine, dried over $\mathrm{MgSO}_{4}$, filtered and concentrated. The crude product was either used without further purification or it was purified by either column chromatography on silica gel or by reverse phase chromatography.

\subsubsection{General Procedure for Boc-Deprotection.}

The compound was dissolved in a solution of $25-50 \%$ TFA in DCM (v:v) to give a clear solution. After $1 \mathrm{~h}$, the reaction was concentrated to give a residue. The residue was dissolved in DCM and concentrated. This was repeated twice to give a residue which was either carried onto the next step without purification or it was purified by reverse phase chromatography.

4.1.6. trans-4-(Aminomethyl)- $N-\{(1 S)-1-[4-(4-c y a n o-3-$ fluorophenyl)-2-pyridinyl]-2-phenylethyl\}cyclohexanecarboxamide, bis-trifluoroacetic acid salt $[(S)-2 \mathrm{~b}]$.

Compound $(S)$-1c was converted to $(S)$-2a using SuzukiMiyaura coupling method B with (4-cyano-3fluorophenyl)boronic acid to give $(S)$-2a. Boc-deprotection gave $0.234 \mathrm{~g}$ (54\% yield over two steps) of $(S)$-2b as a white solid. HRMS m/z calc'd for $\mathrm{C}_{28} \mathrm{H}_{30} \mathrm{~N}_{4} \mathrm{OF}(\mathrm{M}+\mathrm{H})^{+}$: 457.2404. Found 457.2420. ${ }^{1} \mathrm{H}$ NMR $\left(500 \mathrm{MHz}, \mathrm{CD}_{3} \mathrm{OD}\right) \delta: 8.70(\mathrm{~d}, J=5.0 \mathrm{~Hz}$, $1 \mathrm{H}), 7.93-7.90(\mathrm{~m}, 1 \mathrm{H}), 7.77(\mathrm{dd}, J=5.5,1.6 \mathrm{~Hz}, 1 \mathrm{H}), 7.74(\mathrm{dd}$, $J=10.4,1.6 \mathrm{~Hz}, 1 \mathrm{H}), 7.71-7.68(\mathrm{~m}, 2 \mathrm{H}), 7.25-7.23(\mathrm{~m}, 2 \mathrm{H})$, 7.20-7.17 (m, 3H), 5.33 (dd, $J=8.8,7.2 \mathrm{~Hz}, 1 \mathrm{H}), 3.24$ (dd, $J=$ $13.5,6.9 \mathrm{~Hz}, 1 \mathrm{H}), 3.16(\mathrm{dd}, J=13.5,8.5 \mathrm{~Hz}, 1 \mathrm{H}), 2.76(\mathrm{~d}, J=$ $7.2 \mathrm{~Hz}, 2 \mathrm{H}), 2.28-2.23(\mathrm{~m}, 1 \mathrm{H}), 1.85-1.72(\mathrm{~m}, 4 \mathrm{H}), 1.58-1.54(\mathrm{~m}$, 1H), 1.41-1.34 (m, 2H), 1.08-1.00 (m, 2H). ${ }^{19} \mathrm{~F} \mathrm{NMR} \mathrm{(470} \mathrm{MHz,}$ $\left.\mathrm{CD}_{3} \mathrm{OD}\right) \delta$ : $-77.27,-108.45$.

\subsection{7. tert-Butyl $N$-[1-(6-oxo-1,6-dihydropyrimidin-4-yl)-2 -phenylethyl]carbamate (6b).}

To a solution of $0.5 \mathrm{M}$ sodium methoxide in methanol (58.4 $\mathrm{mL}, 29.2 \mathrm{mmol})$ was added formamidine acetate $(1.52 \mathrm{~g}, 14.6$ mmol) to give a clear, colorless solution. Ethyl 4-\{[(tertbutoxy)carbonyl]amino $\}$-3-oxo-5-phenylpentanoate $(\mathbf{6 a})^{34}(3.5 \mathrm{~g}$, $10.4 \mathrm{mmol})$ in $\mathrm{MeOH}(20.9 \mathrm{~mL})$ was added. The resulting clear colorless solution was stirred at rt. After $8 \mathrm{~h}$, the clear, yellow solution was quenched with acetic acid $(1.67 \mathrm{~mL}, 29.2 \mathrm{mmol})$ and the reaction was concentrated to give a solid. The solid was partitioned between water and $\mathrm{CHCl}_{3}(750 \mathrm{~mL})$. The layers were separated and the aqueous layer was extracted with $\mathrm{CHCl}_{3}(250$ $\mathrm{mL}$ ). The organic layers were combined and washed with sat. $\mathrm{NaHCO}_{3}$, brine, dried over $\mathrm{MgSO}_{4}$, filtered, and concentrated to give an off-white solid weighing $3.45 \mathrm{~g}$. Recrystallization from EtOAc gave a white solid weighing $1.49 \mathrm{~g}$. The filtrate was concentrated and then purified by column chromatography on silica gel (gradient elution $0-8 \% \mathrm{MeOH} / \mathrm{CHCl}_{3}$ ) which gave $0.463 \mathrm{~g}$. Combination of $1.49 \mathrm{~g}$ and $0.463 \mathrm{~g}$ gave $1.95 \mathrm{~g}(58 \%$ yield) of $\mathbf{6 b}$, as an off-white solid. LCMS: $m / z 316.2(\mathrm{M}+\mathrm{H})^{+}$. ${ }^{1} \mathrm{H}$ NMR (400MHz, DMSO-d $\mathrm{d}_{6}$ ) $\delta$ : (rotamers) 12.47 (br. s., $\left.1 \mathrm{H}\right)$, $8.18(\mathrm{~s}, 1 \mathrm{H}), 7.37(\mathrm{~d}, J=8.8 \mathrm{~Hz}, 1 \mathrm{H}), 7.31-7.16(\mathrm{~m}, 5 \mathrm{H}), 6.17$ (s, 1H), $4.49-4.40(\mathrm{~m}, 1 \mathrm{H}), 3.08(\mathrm{dd}, J=13.8,4.2 \mathrm{~Hz}, 1 \mathrm{H}), 2.72$ $(\mathrm{dd}, J=13.6,10.5 \mathrm{~Hz}, 1 \mathrm{H}), 1.29$ (s, 8H), 1.16 (br. s., $1 \mathrm{H}) .{ }^{13} \mathrm{C}$ NMR (100 MHz, DMSO-d $\left.{ }_{6}\right) \delta$ : 168.5, 161.9, 155.5, 150.2, $138.9,129.5,128.6,126.6,110.8,78.5,57.1,39.4$ overlaps with DMSO-d $_{6}, 28.6$.

\subsection{8. tert-Butyl $N$-[1-(6-chloropyrimidin-4-yl)-2-phenyl- ethyl]carbamate (6c).}

An orange suspension of $\mathbf{6 b}(4.0 \mathrm{~g}, 12.68 \mathrm{mmol})$ in phosphorus oxychloride $(59.1 \mathrm{~mL}, 634 \mathrm{mmol})$ was warmed to 50 ${ }^{\circ} \mathrm{C}$ to give a dark red solution. After $2 \mathrm{~h}$, the reaction was cooled to $\mathrm{rt}$ and concentrated to give an orange-brown residue. The residue was dissolved in $\mathrm{CH}_{2} \mathrm{Cl}_{2}$ and then concentrated (2x). The residue was dissolved in $\mathrm{CH}_{2} \mathrm{Cl}_{2}$ and then poured into cold $\left(0{ }^{\circ} \mathrm{C}\right)$ sat. $\mathrm{NaHCO}_{3}$. The layers were separated and the aqueous layer was extracted with $\mathrm{CH}_{2} \mathrm{Cl}_{2}(1 \mathrm{x})$. The organic layers were combined and washed with brine, dried over $\mathrm{MgSO}_{4}$, filtered and concentrated to give $2.75 \mathrm{~g}$ of 1-(6-chloropyrimidin-4-yl)-2- 
phenylethan-1-amine as a red foam. LCMS: $234.0(\mathrm{M}+\mathrm{H})^{+} ; 236$ $(\mathrm{M}+2+\mathrm{H})^{+}$

To a dark red solution of 1-(6-chloropyrimidin-4-yl)-2phenylethan-1-amine $(2.73 \mathrm{~g}, 11.7 \mathrm{mmol})$ in $\mathrm{CH}_{2} \mathrm{Cl}_{2}(38.9 \mathrm{~mL})$ was added $\mathrm{Boc}_{2} \mathrm{O}(2.68 \mathrm{~g}, 12.3 \mathrm{mmol})$ and triethylamine $(3.26$ $\mathrm{mL}, 23.4 \mathrm{mmol})$. The reaction was stirred at $\mathrm{rt}$ for $1 \mathrm{~h}$. Then, the reaction was partitioned between $\mathrm{CH}_{2} \mathrm{Cl}_{2} / \mathrm{sat}$. $\mathrm{NaHCO}_{3}$ and the layers were separated. The aqueous layer was extracted with $\mathrm{CH}_{2} \mathrm{Cl}_{2}(1 \mathrm{x})$. The organic layers were combined and washed with brine, dried over $\mathrm{Na}_{2} \mathrm{SO}_{4}$, filtered, and concentrated to give an orange-brown oil. Purification by column chromatography on silica gel (gradient elution 0-20\% EtOAc/Hex) provided $1.17 \mathrm{~g}$ (28\% yield over two steps) of $\mathbf{6 c}$ as a pale, yellow solid. HRMS $\mathrm{m} / \mathrm{z}$ calc'd for $\mathrm{C}_{17} \mathrm{H}_{21} \mathrm{ClN}_{3} \mathrm{O}_{2}(\mathrm{M}+\mathrm{H})^{+}$: 334.1322. Found 334.1325. ${ }^{1} \mathrm{H}$ NMR $\left(400 \mathrm{MHz}, \mathrm{CDCl}_{3}\right) \delta: 8.95(\mathrm{~s}, 1 \mathrm{H}), 7.30-$ $7.18(\mathrm{~m}, 3 \mathrm{H}), 7.05-6.96(\mathrm{~m}, 3 \mathrm{H}), 5.41-5.37(\mathrm{~m}, 1 \mathrm{H}), 4.99-4.92$ $(\mathrm{m}, 1 \mathrm{H}), 3.17(\mathrm{dd}, J=13.6,6.6 \mathrm{~Hz}, 1 \mathrm{H}), 3.08(\mathrm{dd}, J=13.6,7.3$ $\mathrm{Hz}, 1 \mathrm{H}), 1.41$ (bs, 9H). ${ }^{13} \mathrm{C} \mathrm{NMR}\left(100 \mathrm{MHz}, \mathrm{CDCl}_{3}\right) \delta: 170.6$, 161.4, 158.7, 155.0, 136.1, 129.2, 128.6, 127.0, 119.6, 80.1, 56.2, $41.5,28.3$

\subsubsection{Methyl $N$-(4-\{6-[(1S)-1-amino-2-phenylethyl]- pyrimidin-4-yl\}phenyl)carbamate, bis-trifluoroacetic acid salt [(S)-6d].}

Compound $\mathbf{6 c}$ was converted to $\mathbf{6 d}$ according to the SuzukiMiyaura coupling method B with 4-(methoxycarbonylamino)phenylboronic acid, followed by Bocdeprotection which gave $0.143 \mathrm{~g}$ (46\% yield over two steps) of 6d as a white solid. The enantiomers were separated by chiral prep HPLC [Chiralpak AS $5 \times 50 \mathrm{~cm}$; isocratic elution $30 \%$ $\mathrm{MeOH} / \mathrm{EtOH}(1: 1): H e p t a n e ; 50 \mathrm{~mL} / \mathrm{min}$; $220 \mathrm{~nm}]$ which gave $(R)-\mathbf{6 d}$, enantiomer A $(>97 \%$ ee), and $(S)-6 \mathbf{d}$, enantiomer B $\left(>98 \%\right.$ ee). HRMS m/z calc'd for $\mathrm{C}_{20} \mathrm{H}_{21} \mathrm{~N}_{4} \mathrm{O}_{2}(\mathrm{M}+\mathrm{H})^{+}$: 349.1665. Found 349.1663. ${ }^{1} \mathrm{H}$ NMR (500 MHz, $\left.\mathrm{CD}_{3} \mathrm{OD}\right) \delta$ : $9.07(\mathrm{~s}, 1 \mathrm{H}), 7.99(\mathrm{~d}, J=8.8 \mathrm{~Hz}, 2 \mathrm{H}), 7.66(\mathrm{~s}, 1 \mathrm{H}), 7.58(\mathrm{~d}, J=$ $8.8 \mathrm{~Hz}, 2 \mathrm{H}), 7.21-7.28(\mathrm{~m}, 2 \mathrm{H}), 7.15-7.20(\mathrm{~m}, 1 \mathrm{H}), 7.11(\mathrm{~d}, J$ $=7.2 \mathrm{~Hz}, 2 \mathrm{H}), 4.21(\mathrm{t}, J=7.2 \mathrm{~Hz}, 1 \mathrm{H}), 3.76(\mathrm{~s}, 3 \mathrm{H}), 3.11(\mathrm{dd}, J$ $=13.2,7.2 \mathrm{~Hz}, 1 \mathrm{H}), 3.04(\mathrm{dd}, J=13.8,7.7 \mathrm{~Hz}, 1 \mathrm{H})$. For $(S)-6 \mathrm{~d}$ : $[\alpha]_{\mathrm{D}}^{22.4}=+1.05(\mathrm{c}=1.0, \mathrm{MeOH})$. For $(R)-6 \mathrm{~d}:[\alpha]_{\mathrm{D}}^{22.8}=-0.93(\mathrm{c}$ $=1.1, \mathrm{MeOH})$.

\subsubsection{0. tert-Butyl $N$-[(1S)-1-(4-chloropyridin-2-yl)-2-phenyl- ethyl]carbamate $[(S)-7 a]$.}

To a cooled $\left(0{ }^{\circ} \mathrm{C}\right)$ solution of $\mathbf{1 b}(15 \mathrm{~g}, 0.064 \mathrm{~mol})$ in $\mathrm{CH}_{2} \mathrm{Cl}_{2}$ $(150 \mathrm{~mL})$ was added DMAP $(0.78 \mathrm{~g}, 0.0064 \mathrm{~mol})$ followed by the portion wise addition of $\mathrm{Boc}_{2} \mathrm{O}(16.9 \mathrm{~g}, 0.0775 \mathrm{~mol})$. The reaction mixture was allowed to warm to rt and stir overnight. The reaction mixture was concentrated. Column chromatography on silica gel (EtOAc/Hex) gave $9.0 \mathrm{~g}$ (43\% yield) of 7a as a white solid. The enantiomers were separated by chiral prep. SFC [Chiralcel OD-H column: 3 x $25 \mathrm{~cm}, 5 \mu \mathrm{m}$; Pressure 100 bars; Temperature $35^{\circ} \mathrm{C}$; Mobile phase: $88: 12 \mathrm{CO}_{2}: \mathrm{MeOH}$; Flow rate: $120 \mathrm{~mL} / \mathrm{min}$; UV detection: $220 \mathrm{~nm}$ ] which gave $(S)-7 \mathbf{a}$, enantiomer A ( $>99 \%$ ee) and $(R)-7 \mathbf{a}$, enantiomer $\mathrm{B}(>98 \%$ ee). HRMS m/z calc'd for $\mathrm{C}_{18} \mathrm{H}_{22} \mathrm{ClN}_{2} \mathrm{O}_{2}(\mathrm{M}+\mathrm{H})^{+}: 333.1364$. Found 333.1366. LCMS: $333.0(\mathrm{M}+\mathrm{H})^{+}$and $335.0(\mathrm{M}+2+\mathrm{H})^{+} .{ }^{1} \mathrm{H}$ NMR $\left(400 \mathrm{MHz}, \mathrm{CDCl}_{3}\right) \delta: 8.46(\mathrm{~d}, J=5.5 \mathrm{~Hz}, 1 \mathrm{H}), 7.26-7.15$ (m, 4H), $7.04-6.89(\mathrm{~m}, 3 \mathrm{H}), 5.63-5.53(\mathrm{~m}, 1 \mathrm{H}), 5.00-4.91(\mathrm{~m}$, $1 \mathrm{H}), 3.22-3.12(\mathrm{~m}, 1 \mathrm{H}), 3.08(\mathrm{dd}, J=13.2,7.7 \mathrm{~Hz}, 1 \mathrm{H}), 1.42$ (bs, 9H). ${ }^{13} \mathrm{C}$ NMR $\left(125 \mathrm{MHz}, \mathrm{CDCl}_{3}\right) \delta: 161.52,155.09$, $150.02,144.11,136.96,129.37,128.28,126.56,122.58,122.52$, 79.51, 56.58, 42.42, 28.31. $[\alpha]_{\mathrm{D}}^{25}=-5.73\left(\mathrm{c}=1.0 ; \mathrm{CHCl}_{3}\right)$.

4.1.11. Methyl $N$-(4-\{2-[(1S)-1-amino-2-phenylethyl]pyridin4-yl\}phenyl)carbamate $[(S)-7 b]$.
To a flame-dried RBF was added $(S)-7 \mathbf{a}(1.0 \mathrm{~g}, 3.0 \mathrm{mmol})$, 4(methoxycarbonylamino) phenylboronic acid $(0.879 \mathrm{~g}, 4.51$ $\mathrm{mmol}), \mathrm{Cs}_{2} \mathrm{CO}_{3}(1.47 \mathrm{~g}, 4.51 \mathrm{mmol}), \mathrm{Pd}_{2} \mathrm{dba}_{3}(0.138 \mathrm{~g}, 0.15$ $\mathrm{mmol})$, and tri-tert-butylphosphine tetrafluoroborate $(0.105 \mathrm{~g}$, $0.361 \mathrm{mmol})$. The flask was purged with argon for several minutes and then degassed 1,4-dioxane $(15 \mathrm{~mL})$ was added. The reaction mixture was stirred at $\mathrm{rt}$ for $1 \mathrm{~h}$ and then warmed to 90 ${ }^{\circ} \mathrm{C}$. After $4 \mathrm{~h}$ the reaction was stopped and cooled to $\mathrm{rt}$. The resulting gray/black suspension was filtered through a 0.45 micron glass membrane filter to give an orange filtrate. The filtrate was concentrated to give a yellow foam. Column chromatography on silica gel (gradient elution $0-50 \%$ EtOAc:Hex) gave, after lyophilization, $1.16 \mathrm{~g}$ (86\% yield) of tert-butyl $N$-[(1S)-1- (4-\{4-[(methoxycarbonyl)amino]phenyl $\}-$ pyridin-2-yl)-2-phenylethyl]carbamate, as a white solid. HRMS $\mathrm{m} / \mathrm{z}$ calc'd for $\mathrm{C}_{26} \mathrm{H}_{30} \mathrm{~N}_{3} \mathrm{O}_{4}(\mathrm{M}+\mathrm{H})^{+}:$448.2240. Found 448.2231. ${ }^{1} \mathrm{H}$ NMR $\left(500 \mathrm{MHz}, \mathrm{CDCl}_{3}\right) \delta: 8.56(\mathrm{~d}, J=4.9 \mathrm{~Hz}$, 1H), 7.50 - $7.29(\mathrm{~m}, 5 \mathrm{H}), 7.25-7.14(\mathrm{~m}, 3 \mathrm{H}), 7.05-6.97(\mathrm{~m}$, 3H), 6.92 (br. s., $1 \mathrm{H}), 5.88(\mathrm{~d}, J=7.7 \mathrm{~Hz}, 1 \mathrm{H}), 5.05-4.96(\mathrm{~m}$, $1 \mathrm{H}), 3.79(\mathrm{~s}, 3 \mathrm{H}), 3.28(\mathrm{dd}, J=13.2,5.5 \mathrm{~Hz}, 1 \mathrm{H}), 3.02(\mathrm{dd}, J=$ 13.2, $8.2 \mathrm{~Hz}, 1 \mathrm{H}), 1.48-1.33(\mathrm{~m}, 9 \mathrm{H}) .{ }^{13} \mathrm{C} \mathrm{NMR}(100 \mathrm{MHz}$, $\left.\mathrm{CDCl}_{3}\right) \delta: 159.8,155.3,153.8,149.5,147.7,138.9,137.6,132.7$, $129.5,128.2,127.6,126.4,119.8,118.8,79.3,57.0,52.4,43.0$, 28.4. $[\alpha]_{\mathrm{D}}^{23.4}=-47.43(\mathrm{c}=1.30, \mathrm{MeOH})$.

A clear, yellow solution of tert-butyl $N$-[(1S)-1-(4-\{4[(methoxycarbonyl)amino]-phenyl $\}$ pyridin-2-yl)-2-phenylethyl]carbamate $(0.850 \mathrm{~g}, 1.90 \mathrm{mmol})$ in $15 \%$ TFA/DCM $(38.0 \mathrm{~mL})$ was stirred at rt. After $1.5 \mathrm{~h}$, the reaction was concentrated to give a clear, yellow residue. The residue was dissolved in DCM and concentrated. This was repeated three times to give a yellow residue. The residue was dissolved in DCM and then washed with sat. $\mathrm{NaHCO}_{3}$, brine, dried over $\mathrm{MgSO}_{4}$, filtered and concentrated to give a white foam. Column chromatography on silica gel (gradient elution $0-10 \% \mathrm{MeOH} / \mathrm{DCM}$ ) gave $0.575 \mathrm{~g}$ (87\% yield) of $(S)-7 \mathbf{b}$ as a white foam. LCMS: $348.4(\mathrm{M}+\mathrm{H})^{+}$. ${ }^{1} \mathrm{H}$ NMR $\left(400 \mathrm{MHz}, \mathrm{CD}_{3} \mathrm{OD}\right) \delta: 8.50(\mathrm{~d}, J=5.5 \mathrm{~Hz}, 1 \mathrm{H}), 7.61-$ $7.53(\mathrm{~m}, 4 \mathrm{H}), 7.51(\mathrm{dd}, J=5.5,1.6 \mathrm{~Hz}, 1 \mathrm{H}), 7.44(\mathrm{~d}, J=1.6 \mathrm{~Hz}$, $1 \mathrm{H}), 7.25-7.19(\mathrm{~m}, 2 \mathrm{H}), 7.19-7.13(\mathrm{~m}, 1 \mathrm{H}), 7.11-7.06(\mathrm{~m}$, $2 \mathrm{H}), 4.24(\mathrm{t}, J=7.1 \mathrm{~Hz}, 1 \mathrm{H}), 3.75(\mathrm{~s}, 3 \mathrm{H}), 3.10(\mathrm{dd}, J=13.2,7.1$ $\mathrm{Hz}, 1 \mathrm{H}), 3.02(\mathrm{dd}, J=13.2,7.1 \mathrm{~Hz}, 1 \mathrm{H}) .{ }^{13} \mathrm{C} \mathrm{NMR}(125 \mathrm{MHz}$, $\left.\mathrm{CD}_{3} \mathrm{OD}\right) \delta$ : $164.8,156.4,150.3,141.8,139.7,133.3,130.6$, $129.6,128.7,127.6,121.0,120.4,120.1,59.8,52.8,46.1$. $[\alpha]_{\mathrm{D}}^{23.7}=+12.63(\mathrm{c}=1.21, \mathrm{MeOH})$.

\subsubsection{2. (2E)-3-[5-Chloro-2-(1H-1,2,3,4-tetrazol-1-yl)phenyl]- prop-2-enoic acid (7c).}

To a cooled $\left(0{ }^{\circ} \mathrm{C}\right)$ suspension of $\mathrm{NaH}(0.262 \mathrm{~g}, 6.56 \mathrm{mmol})$ in THF (27.3 $\mathrm{mL})$ was added drop wise methyl 2-(dimethoxyphosphoryl)acetate $(1.15 \mathrm{~mL}, 7.10 \mathrm{mmol})$. The resulting thick, white suspension was diluted with additional THF $(15 \mathrm{~mL})$ to facilitate mixing, and then the reaction was allowed to warm to rt. After $45 \mathrm{~min}$, a slightly cloudy blue solution of 5-chloro-2-(1H-1,2,3,4-tetrazol-1-yl)benzaldehyde ${ }^{39}$ $(1.14 \mathrm{~g}, 5.46 \mathrm{mmol})$ in THF $(8 \mathrm{~mL})$ was added. The yellowgreen suspension was stirred vigorously. After $30 \mathrm{~min}$, the reaction was poured into cold sat. $\mathrm{NH}_{4} \mathrm{Cl}$ and extracted with EtOAc. The organic layers were combined and washed with brine, dried over $\mathrm{Na}_{2} \mathrm{SO}_{4}$, filtered and concentrated to give a green-blue solid (1.76 g). The solid was dissolved in EtOAc and filtered through a plug of silica gel and eluted with EtOAc. The filtrate was concentrated to give a greenish solid (1.36 g). Recrystallization from EtOAc gave an off-white solid $(0.476 \mathrm{~g})$. Additional product was obtained by concentrating the filtrate, adding methanol, sonicating, and collecting the resulting solid by filtration. A total of $0.829 \mathrm{~g}(57 \%$ yield $)$ of methyl (2E)-3-[5-chloro-2-(1H-1,2,3,4-tetrazol-1-yl)phenyl]prop-2- 
enoate was obtained. LCMS: $265.1(\mathrm{M}+\mathrm{H})^{+} ; 287.2(\mathrm{M}+\mathrm{Na})^{+}$. ${ }^{1} \mathrm{H} \mathrm{NMR}\left(500 \mathrm{MHz}, \mathrm{CDCl}_{3}\right) \delta: 8.80(\mathrm{~s}, 1 \mathrm{H}), 7.78(\mathrm{~d}, J=2.2 \mathrm{~Hz}$, $1 \mathrm{H}), 7.58(\mathrm{dd}, J=8.8,2.2 \mathrm{~Hz}, 1 \mathrm{H}), 7.42(\mathrm{~d}, J=8.2 \mathrm{~Hz}, 1 \mathrm{H}), 7.25$ $(\mathrm{d}, J=16.0 \mathrm{~Hz}, 1 \mathrm{H}), 6.45(\mathrm{~d}, J=16.0 \mathrm{~Hz}, 1 \mathrm{H}), 3.78(\mathrm{~s}, 3 \mathrm{H})$.

To a white suspension of methyl (2E)-3-[5-chloro-2(1H-1,2,3,4-tetrazol-1-yl)phenyl]prop-2-enoate $(0.140 \mathrm{~g}, \quad 0.53$ $\mathrm{mmol})$ in $\mathrm{MeOH}(3.0 \mathrm{~mL})$ was added $1.0 \mathrm{M} \mathrm{NaOH}(1.59 \mathrm{ml}$, $1.59 \mathrm{mmol}$ ). The resulting suspension was stirred vigorously at $\mathrm{rt}$ for $2.5 \mathrm{~h}$. The yellow suspension was neutralized with $1.0 \mathrm{~N} \mathrm{HCl}$ $(1.60 \mathrm{~mL})$, and concentrated to give a beige solid. The solid was partitioned between $1.0 \mathrm{~N} \mathrm{HCl}$ and EtOAc, and then the layers were separated. The organic layer was washed with brine, dried over $\mathrm{Na}_{2} \mathrm{SO}_{4}$, filtered and concentrated to give $0.137 \mathrm{~g}(100 \%$ yield) of 7c as a white solid. LCMS: $251.1(\mathrm{M}+\mathrm{H})^{+}$. ${ }^{1} \mathrm{H}$ NMR (500 MHz, DMSO-d 6 ) $\delta: 12.72(\mathrm{~s}, 1 \mathrm{H}), 9.87(\mathrm{~s}, 1 \mathrm{H}), 8.24$ (d, $J=$ $2.2 \mathrm{~Hz}, 1 \mathrm{H}), 7.77(\mathrm{dd}, J=8.8,2.2 \mathrm{~Hz}, 1 \mathrm{H}), 7.73(\mathrm{~d}, J=8.2 \mathrm{~Hz}$, $1 \mathrm{H}), 6.98(\mathrm{~d}, J=16.0 \mathrm{~Hz}, 1 \mathrm{H}), 6.70(\mathrm{~d}, J=16.0 \mathrm{~Hz}, 1 \mathrm{H})$.

\subsubsection{2,5-Dioxopyrrolidin-1-yl (2E)-3-[5-chloro-2-(1H- 1,2,3,4-tetrazol-1-yl)phenyl]prop- 2-enoate (7d).}

To a solution of 7c $(5.00 \mathrm{~g}, 19.95 \mathrm{mmol})$ in THF $(100 \mathrm{~mL})$ and DMF $(10 \mathrm{~mL})$ was added 1-hydroxypyrrolidine-2,5-dione (2.53 $\mathrm{g}, 21.94 \mathrm{mmol})$ and DIC $(3.42 \mathrm{~mL}, 21.94 \mathrm{mmol})$. The reaction was stirred overnight. The white precipitate that formed was collected by filtration, washed with methanol and water, and then dried under vacuum to give $7.0 \mathrm{~g}(100 \%$ yield $)$ of $\mathbf{7 d}$ as a white solid. LCMS: $348.0(\mathrm{M}+\mathrm{H})^{+}$. ${ }^{1} \mathrm{H}$ NMR $\left(400 \mathrm{MHz}\right.$, acetone- $\left.\mathrm{d}_{6}\right)$ $\delta: 2.80(\mathrm{~s}, 4 \mathrm{H}), 6.94(\mathrm{~d}, J=15.82 \mathrm{~Hz}, 1 \mathrm{H}), 7.45(\mathrm{~d}, J=15.82 \mathrm{~Hz}$, $1 \mathrm{H}), 7.69-7.76(\mathrm{~m}, J=8.85,2.2 \mathrm{~Hz}, 2 \mathrm{H}), 8.23(\mathrm{~d}, J=2.2 \mathrm{~Hz}$, 1H), 9.52 ( $\mathrm{s}, 1 \mathrm{H})$.

\subsubsection{4. (R)- $N$-[(1S)-1-(2-Bromopyridin-4-yl)-2-phenylethyl]- 2-methylpropane-2-sulfinamide [ $R, S)-7 f]$.}

To a solution of 2-bromopyridine-4-carbaldehyde (7e, $1 \mathrm{~g}$, $5.38 \mathrm{mmol})$ and $\mathrm{Ti}(\mathrm{OEt})_{4}(5.64 \mathrm{~mL}, 26.9 \mathrm{mmol})$ in $\mathrm{CH}_{2} \mathrm{Cl}_{2}(10.75$ $\mathrm{mL})$ was added $(R)$-2-methylpropane-2-sulfinamide $(0.717 \mathrm{~g}$, $5.91 \mathrm{mmol})$. The reaction was stirred overnight at $\mathrm{rt}$. The reaction mixture was poured into a rapidly stirred mixture of brine. The resulting suspension was filtered through a plug of Celite ${ }^{\circledR}$ and the filter cake was washed with $\mathrm{CH}_{2} \mathrm{Cl}_{2}$ to give a biphasic filtrate. The layers were separated. The organic layer was washed with brine, dried over $\mathrm{MgSO}_{4}$, filtered and concentrated. Column chromatography on silica gel (gradient elution $0-30 \%$ EtOAc/Hex) gave $0.92 \mathrm{~g}$ (59\% yield) of $(R)-N$-[(1E)-(2-bromopyridin-4-yl)methylidene]-2-methylpropan e-2-sulfinamide as a yellow oil. LCMS: $288.9(\mathrm{M}+\mathrm{H})^{+}$and 290.9 $(\mathrm{M}+2+\mathrm{H})^{+} .{ }^{1} \mathrm{H} \mathrm{NMR}\left(400 \mathrm{MHz}, \mathrm{CDCl}_{3}\right) \delta: 8.56-8.52(\mathrm{~m}, 2 \mathrm{H})$, $7.89(\mathrm{~s}, 1 \mathrm{H}), 7.64(\mathrm{dd}, J=4.9,1.6 \mathrm{~Hz}, 1 \mathrm{H}), 1.29(\mathrm{~s}, 9 \mathrm{H})$.

To a cooled $\left(-78 \quad{ }^{\circ} \mathrm{C}\right)$ solution of (R)- $N$-[(1E)-(2-bromopyridin-4-yl)methylidene]-2-methylpropane-2-sulfinamide $(0.686 \mathrm{~g}, 2.37 \mathrm{mmol})$ in $1: 1 \mathrm{Et}_{2} \mathrm{O}: \mathrm{CH}_{2} \mathrm{Cl}_{2}$ $(20 \mathrm{~mL})$ was added $1.0 \mathrm{M}$ benzylmagnesium bromide in THF $(2.61 \mathrm{~mL}, 2.61 \mathrm{mmol})$. The reaction was allowed to slowly warm to $\mathrm{rt}$ and the reaction was stirred overnight. The reaction was cooled to $0{ }^{\circ} \mathrm{C}$ and additional $1.0 \mathrm{M}$ benzylmagnesium bromide in THF $(0.52 \mathrm{~mL})$ was added. After $2 \mathrm{~h}$, the reaction was quenched with sat. $\mathrm{NH}_{4} \mathrm{Cl}$ and diluted with EtOAc. The layers were separated. The organic layer was washed with brine, dried over $\mathrm{MgSO}_{4}$, filtered and concentrated. Column chromatography on silica gel (gradient elution 0-50\% EtOAc/Hex) gave $0.370 \mathrm{~g}$ (41\% yield) of $(R, S)-7 \mathbf{f}$ as a brown oil and $0.273 \mathrm{~g}$ (30\% yield) of $(R, R)-7 \mathbf{f}$ as an off-white solid. LCMS: $380.9(\mathrm{M}+\mathrm{H})^{+}$and 382.9 $(\mathrm{M}+2+\mathrm{H})^{+} .{ }^{1} \mathrm{H}$ NMR $\left(400 \mathrm{MHz}, \mathrm{CDCl}_{3}\right) \delta: 8.30(\mathrm{~d}, J=4.9 \mathrm{~Hz}$, $1 \mathrm{H}), 7.40(\mathrm{~s}, 1 \mathrm{H}), 7.33-7.23(\mathrm{~m}, 3 \mathrm{H}), 7.12(\mathrm{dd}, J=4.9,1.6 \mathrm{~Hz}$, 1H), $7.09-7.05(\mathrm{~m}, 2 \mathrm{H}), 4.66-4.60(\mathrm{~m}, 1 \mathrm{H}), 3.58(\mathrm{~d}, J=2.2 \mathrm{~Hz}$,
$1 \mathrm{H}), 3.12(\mathrm{dd}, J=13.7,6.6 \mathrm{~Hz}, 1 \mathrm{H}), 3.00(\mathrm{dd}, J=13.7,8.2 \mathrm{~Hz}$, $1 \mathrm{H}), 1.17$ (s, 9H).

\subsubsection{Methyl $N$-(4-\{4-[(1S)-1-amino-2-phenylethyl]pyridin- 2-yl\}phenyl)carbamate, $2 \mathrm{HCl}[(S)-7 \mathrm{~g}]$.}

To a flame-dried RBF was added $(R, S)-7 f(0.060 \mathrm{~g}, 0.157$ $\mathrm{mmol}), 4-($ methoxy-carbonylamino)phenylboronic acid $(0.046 \mathrm{~g}$, $0.236 \mathrm{mmol}), \mathrm{Cs}_{2} \mathrm{CO}_{3}(0.077 \mathrm{~g}, 0.236 \mathrm{mmol}), \mathrm{Pd}_{2} \mathrm{dba}_{3}(0.0072 \mathrm{~g}$, $0.0079 \mathrm{mmol})$, and tri-tert-butylphosphine tetrafluoroborate $(0.0055 \mathrm{~g}, 0.019 \mathrm{mmol})$. The flask was purged with argon for several minutes and then degassed 1,4-dioxane $(2 \mathrm{~mL})$ was added. The reaction mixture was stirred at $\mathrm{rt}$ for $1 \mathrm{~h}$ and then warmed to $90{ }^{\circ} \mathrm{C}$. After $16 \mathrm{~h}$ the reaction was stopped and cooled to rt. The suspension was filtered and the filtrate was concentrated. Column chromatography on silica gel (gradient elution $0-50 \%$ EtOAc:Hex) gave, $0.040 \mathrm{~g}$ (56\% yield) of methyl $N$-(4-\{4-[(1S)-1-\{[(R)-2-methylpropane-2-sulfinyl]amino $\}$-2-phe nylethyl]pyridin-2-yl $\}$ phenyl)carbamate, as a brown solid. LCMS: $452.1(\mathrm{M}+\mathrm{H})^{+}$. ${ }^{1} \mathrm{H}$ NMR $\left(400 \mathrm{MHz}, \mathrm{CDCl}_{3}\right) \delta: 8.60(\mathrm{~d}$, $J=4.9 \mathrm{~Hz}, 1 \mathrm{H}), 7.92-7.87(\mathrm{~m}, 2 \mathrm{H}), 7.55(\mathrm{~s}, 1 \mathrm{H}), 7.50(\mathrm{~d}, J=8.8$ $\mathrm{Hz}, 2 \mathrm{H}), 7.33$ - 7.22 (m, 3H), 7.13 - 7.08 (m, 3H), 6.89 (s, 1H), $4.74-4.68(\mathrm{~m}, 1 \mathrm{H}), 3.79(\mathrm{~s}, 3 \mathrm{H}), 3.61(\mathrm{~d}, J=2.2 \mathrm{~Hz}, 1 \mathrm{H}), 3.14$ (dd, $J=13.7,6.0 \mathrm{~Hz}, 1 \mathrm{H}), 3.05$ (dd, $J=13.7,8.2 \mathrm{~Hz}, 1 \mathrm{H}$ ), 1.18 (s, 9H).

To a solution of methyl $N-(4-\{4-[(1 S)-1-\{[(R)-2-m e t h y l-$ propane-2-sulfinyl]amino $\}$-2-phenylethyl]pyridin-2-

yl phenyl)carbamate $(0.040 \mathrm{~g}, 0.089 \mathrm{mmol})$ in $\mathrm{MeOH}(1 \mathrm{~mL})$ was added $4 \mathrm{M} \mathrm{HCl}$ in dioxane $(1 \mathrm{~mL})$. The reaction mixture was stirred at rt. After $30 \mathrm{~min}$, the reaction was concentrated to near dryness. Diethyl ether was added to give a yellow suspension. The solid was collected by filtration. The solid was rinsed with diethyl ether and dried to give $0.029 \mathrm{~g}$ (78\% yield) of $(S)-\mathbf{7 g}$ as a yellow solid. LCMS: $348.1(\mathrm{M}+\mathrm{H})^{+}$. ${ }^{1} \mathrm{H}$ NMR $(400 \mathrm{MHz}$, $\left.\mathrm{CD}_{3} \mathrm{OD}\right) \delta: 8.78(\mathrm{~d}, J=6.0 \mathrm{~Hz}, 1 \mathrm{H}), 8.34(\mathrm{~d}, J=1.1 \mathrm{~Hz}, 1 \mathrm{H})$, $7.93-7.86(\mathrm{~m}, 3 \mathrm{H}), 7.77(\mathrm{~d}, J=8.8 \mathrm{~Hz}, 2 \mathrm{H}), 7.36-7.23(\mathrm{~m}, 5 \mathrm{H})$, $5.02(\mathrm{t}, J=7.7 \mathrm{~Hz}, 1 \mathrm{H}), 3.78(\mathrm{~s}, 3 \mathrm{H}), 3.50(\mathrm{dd}, J=13.7,6.6 \mathrm{~Hz}$, $1 \mathrm{H}), 3.37$ - $3.32(\mathrm{~m}, 1 \mathrm{H})$ partial overlap with $\mathrm{CD}_{3} \mathrm{OD}$.

\subsubsection{6. trans- $N$ - $\{(1 S)-1-[4-(3-A m i n o-1 H$-indazol-6-yl)-2- pyridinyl]-2-phenylethyl\}-4-(aminomethyl)cyclohexane- carboxamide, bis-trifluoroacetic acid salt $[(S)-2]$}

A suspension of $(S)-\mathbf{2 b}(0.095 \mathrm{~g}, 0.138 \mathrm{mmol})$ in n-butanol $(3.0 \mathrm{~mL})$ and hydrazine monohydrate $(1.0 \mathrm{~mL})$ was microwaved at $150{ }^{\circ} \mathrm{C}$ for $10 \mathrm{~min}$. The resulting clear, bright yellow solution was concentrated. Purification by reverse phase chromatography gave $0.069 \mathrm{~g}$ (71\% yield) of $(S)-2$, as a yellow solid. Analytical HPLC Purity, $100 \%$. HRMS m/z calc'd for $\mathrm{C}_{28} \mathrm{H}_{33} \mathrm{~N}_{6} \mathrm{O}(\mathrm{M}+\mathrm{H})^{+}$: 469.2716. Found 469.2705. ${ }^{1} \mathrm{H}$ NMR $\left(500 \mathrm{MHz}, \mathrm{CD}_{3} \mathrm{OD}\right) \delta$ : $8.69(\mathrm{~d}, J=5.5 \mathrm{~Hz}, 1 \mathrm{H}), 8.02(\mathrm{~d}, J=8.2 \mathrm{~Hz}, 1 \mathrm{H}), 7.92(\mathrm{dd}, J=$ 5.8, $1.9 \mathrm{~Hz}, 1 \mathrm{H}), 7.85$ (bs, $1 \mathrm{H}), 7.75$ (bs, $1 \mathrm{H}), 7.49$ (dd, $J=8.5$, $1.4 \mathrm{~Hz}, 1 \mathrm{H}), 7.28-7.25(\mathrm{~m}, 2 \mathrm{H}), 7.22-7.19(\mathrm{~m}, 3 \mathrm{H}), 5.35(\mathrm{t}, J=$ $7.7 \mathrm{~Hz}, 1 \mathrm{H}), 3.25(\mathrm{~d}, J=8.2 \mathrm{~Hz}, 2 \mathrm{H}), 2.77(\mathrm{~d}, J=6.6 \mathrm{~Hz}, 2 \mathrm{H})$, 2.30-2.25 (m, 1H), 1.86-1.74 (m, 4H), 1.59-1.54 (m, 1H), 1.43$1.33(\mathrm{~m}, 2 \mathrm{H}), 1.10-1.01(\mathrm{~m}, 2 \mathrm{H}) .{ }^{13} \mathrm{C}$ NMR $\left(100 \mathrm{MHz}, \mathrm{CD}_{3} \mathrm{OD}\right)$ $\delta: 178.6,162.3(\mathrm{q}, J=34.9 \mathrm{~Hz}), 160.3,155.8,148.7,145.8$, $144.2,139.9,137.9,130.4,129.7,128.2,123.84,123.75,123.4$, $121.2,117.8$ (q, $J=289.6 \mathrm{~Hz}), 115.1,111.6,56.2,46.2,45.3$, $41.6,36.8,30.3,30.2,29.8,29.4 . \quad[\alpha]_{\mathrm{D}}{ }^{25.2}=+5.52(\mathrm{c}=0.80$; $\mathrm{MeOH})$

\subsubsection{7. trans-4-(Aminomethyl)- $N-\{(1 S)-1-[4-(3-h y d r o x y-1 H-$ indazol-5-yl)-2-pyridinyl]-2-phenylethyl\}cyclohexane- carboxamide, bis-trifluoroacetic acid salt $[(S)-10]$.}

Compound $(S)$-1c was converted to $(S)$-2f using SuzukiMiyaura coupling method B with 5-(dihydroxyboranyl)-2fluorobenzoic acid followed by Boc-deprotection. Compound 
$(S)$-2f was converted to $(S)$-10 $(0.150 \mathrm{~g}, 72 \%$ yield over three steps, yellow solid) according to the procedure described in $(S)-2$, with the exception that the reaction was microwaved at $160{ }^{\circ} \mathrm{C}$ for $1 \mathrm{~h}$. Analytical HPLC Purity, 100\%. HRMS m/z calc'd for $\mathrm{C}_{28} \mathrm{H}_{32} \mathrm{~N}_{5} \mathrm{O}_{2}(\mathrm{M}+\mathrm{H})^{+}:$470.2556. Found 470.2544. ${ }^{1} \mathrm{H} \mathrm{NMR}$ $\left(500 \mathrm{MHz}, \mathrm{CD}_{3} \mathrm{OD}\right) \delta: 8.58(\mathrm{~d}, J=5.5 \mathrm{~Hz}, 1 \mathrm{H}), 8.27(\mathrm{~s}, 1 \mathrm{H})$, $8.08-8.04(\mathrm{~m}, 2 \mathrm{H}), 7.92(\mathrm{~d}, J=8.8 \mathrm{~Hz}, 1 \mathrm{H}), 7.48(\mathrm{~d}, J=8.8 \mathrm{~Hz}$, $1 \mathrm{H}), 7.31-7.25(\mathrm{~m}, 2 \mathrm{H}), 7.25-7.19(\mathrm{~m}, 3 \mathrm{H}), 5.34(\mathrm{t}, J=8.0 \mathrm{~Hz}$, $1 \mathrm{H}), 3.31-3.25(\mathrm{~m}, 2 \mathrm{H})$ overlap with $\mathrm{CD}_{3} \mathrm{OD}, 2.77(\mathrm{~d}, J=7.1$ $\mathrm{Hz}, 2 \mathrm{H}), 2.34-2.24(\mathrm{~m}, 1 \mathrm{H}), 1.90-1.80(\mathrm{~m}, 3 \mathrm{H}), 1.80-1.72(\mathrm{~m}$, $1 \mathrm{H}), 1.63-1.51(\mathrm{~m}, 1 \mathrm{H}), 1.45-1.31(\mathrm{~m}, 2 \mathrm{H}), 1.13-0.99(\mathrm{~m}$, 2H). ${ }^{13} \mathrm{C}$ NMR (125 MHz, CD $\left.{ }_{3} \mathrm{OD}\right) \delta: 179.0,160.7,159.2$, $158.4,146.1,142.4,137.3,130.5,129.9,129.7,128.5,127.2$, 124.0, 123.2, 122.6, 115.7, 113.4, 55.4, 46.3, 45.3, 41.2, 36.8, $30.4,30.3,29.8,29.4 .[\alpha]_{\mathrm{D}}^{24.8}=+1.79(\mathrm{c}=1.41, \mathrm{MeOH})$.

\subsubsection{Methyl (4-\{2-[(1S)-1-(\{[trans-4-(aminomethyl)-} cyclohexyl]0carbonyl\}amino)-2-phenylethyl]-4-pyridinyl\}phenyl)carbamate, bis-trifluoroacetic acid salt [(S)-17].

Compound $(S)$-1c was converted to $(S)$-4f using SuzukiMiyaura coupling method A with 4-(methoxy-carbonylamino)phenylboronic acid. Compound (S)-4f was converted to $(S)-\mathbf{1 7}$ according to the Boc-deprotection procedure which gave $0.125 \mathrm{~g}$ (87\% yield over two steps) of $(S)-\mathbf{1 7}$ as a white solid. Analytical HPLC Purity, $100 \%$. HRMS m/z calc'd for $\mathrm{C}_{29} \mathrm{H}_{35} \mathrm{~N}_{4} \mathrm{O}_{3}$ 487.2709 $(\mathrm{M}+\mathrm{H})^{+}$: $\quad$ Found 487.2706. ${ }^{1} \mathrm{H}$ NMR $(500 \mathrm{MHz}$, $\left.\mathrm{CD}_{3} \mathrm{OD}\right) \delta: 8.57(\mathrm{~d}, J=6.0 \mathrm{~Hz}, 1 \mathrm{H}), 8.02(\mathrm{~d}, J=1.6 \mathrm{~Hz}, 1 \mathrm{H})$, $7.98(\mathrm{dd}, J=6.0,1.6 \mathrm{~Hz}, 1 \mathrm{H}), 7.82-7.77(\mathrm{~m}, 2 \mathrm{H}), 7.69-7.64$ $(\mathrm{m}, 2 \mathrm{H}), 7.29-7.24(\mathrm{~m}, 2 \mathrm{H}), 7.24-7.19(\mathrm{~m}, 3 \mathrm{H}), 5.35(\mathrm{t}, J=8.0$ $\mathrm{Hz}, 1 \mathrm{H}), 3.77$ (s, 3H), $3.26(\mathrm{~d}, J=8.2 \mathrm{~Hz}, 2 \mathrm{H}), 2.77$ (d, $J=7.1$ $\mathrm{Hz}, 2 \mathrm{H}), 2.35-2.25(\mathrm{~m}, 1 \mathrm{H}), 1.91-1.80(\mathrm{~m}, 3 \mathrm{H}), 1.79-1.71(\mathrm{~m}$, $1 \mathrm{H}), 1.63-1.51(\mathrm{~m}, 1 \mathrm{H}), 1.44-1.31(\mathrm{~m}, 2 \mathrm{H}), 1.13-0.99(\mathrm{~m}$, 2H). ${ }^{13} \mathrm{C}$ NMR $\left(125 \mathrm{MHz}, \mathrm{CD}_{3} \mathrm{OD}\right) \delta: 178.5,159.8,156.1$, 155.5 (bs), 145.0 (bs), 143.7, 137.9, 130.5, 130.4, 129.6, 129.5, 128.0, 122.2, 121.4, 120.0, 56.0, 52.7, 46.1, 45.3, 41.5, 36.7, $30.3,30.2,29.7,29.4 .[\alpha]_{\mathrm{D}}^{22.3}=-4.98(\mathrm{c}=1.02, \mathrm{MeOH})$.

\subsubsection{Methyl (4-\{6-[(1S)-1-(\{[trans-4-(aminomethyl)-} cyclohexyl]carbonyl\}amino)-2-phenylethyl]-4-pyrimidinyl\}phenyl)carbamate, bis-trifluoroacetic acid salt [(S)-21].

Compound (S)-6d was converted to $(S)$-21 according to the procedure $(S)$-1c, followed by Boc-deprotection which gave $0.034 \mathrm{~g}$ (37\% yield over two steps) of $(S)$-21 as a pale, yellow solid. Analytical HPLC Purity, 99.7\%. HRMS m/z calc'd for $\mathrm{C}_{28} \mathrm{H}_{34} \mathrm{~N}_{5} \mathrm{O}_{3}(\mathrm{M}+\mathrm{H})^{+}$: 488.2662 . Found 488.2668. ${ }^{1} \mathrm{H}$ NMR $\left(400 \mathrm{MHz}, \mathrm{CD}_{3} \mathrm{OD}\right) \delta: 9.55(\mathrm{~s}, 1 \mathrm{H}), 9.09(\mathrm{~d}, J=1.1 \mathrm{~Hz}, 1 \mathrm{H})$, $8.42(\mathrm{~d}, J=8.2 \mathrm{~Hz}, 1 \mathrm{H}), 8.01(\mathrm{~d}, J=8.8 \mathrm{~Hz}, 2 \mathrm{H}), 7.68(\mathrm{~s}, 1 \mathrm{H})$, $7.60(\mathrm{~d}, J=8.8 \mathrm{~Hz}, 2 \mathrm{H}), 7.28-7.16(\mathrm{~m}, 5 \mathrm{H}), 5.29-5.21(\mathrm{~m}, 1 \mathrm{H})$, $3.76(\mathrm{~s}, 3 \mathrm{H}), 3.26(\mathrm{dd}, J=13.7,6.0 \mathrm{~Hz}, 1 \mathrm{H}), 3.08(\mathrm{dd}, J=13.7$, $8.8 \mathrm{~Hz}, 1 \mathrm{H}), 2.77(\mathrm{~d}, J=7.1 \mathrm{~Hz}, 2 \mathrm{H}), 2.31-2.21(\mathrm{~m}, 1 \mathrm{H}), 1.89-$ $1.80(\mathrm{~m}, 3 \mathrm{H}), 1.75-1.67(\mathrm{~m}, 1 \mathrm{H}), 1.63-1.49(\mathrm{~m}, 1 \mathrm{H}), 1.48-$ $1.30(\mathrm{~m}, 2 \mathrm{H}), 1.12-0.99(\mathrm{~m}, 2 \mathrm{H}) .{ }^{13} \mathrm{C} \mathrm{NMR}(125 \mathrm{MHz}$, $\left.\mathrm{CD}_{3} \mathrm{OD}\right) \delta: 178.3,171.2,165.4,159.7,156.3,143.7,138.9$, $131.8,130.5,129.6,129.3,127.9,119.7,115.3,57.1,52.8,46.3$, $45.6,41.7,36.9,30.5,30.4,29.9,29.6 .[\alpha]_{D}{ }^{24.4}=-17.8(\mathrm{c}=0.87$, $\mathrm{MeOH})$.

\subsubsection{Methyl $N-(4-\{2-[(1 S)-1-[(2 \mathrm{E})-3-[5-c h l o r o-2-(1 \mathrm{H}-$} 1,2,3,4-tetrazol-1-yl)phenyl]prop- 2-enamido]-2-phenylethyl]pyridin-4-yl\}phenyl)carbamate, trifluoroacetic acid [(S)-24].

To a flask containing $(S)-7 \mathbf{b}(0.100 \mathrm{~g}, 0.29 \mathrm{mmol})$ and 2,5-dioxopyrrolidin-1-yl (2E)-3-[5-chloro-2-(1H-1,2,3,4-tetrazol1-yl)phenyl]prop-2-enoate (7d, $0.100 \mathrm{~g}, 0.29 \mathrm{mmol})$ was added DMF $(1.9 \mathrm{~mL})$ and Hunig's base $(0.151 \mathrm{~mL}, 0.86 \mathrm{mmol})$. The resulting clear, yellow solution was stirred at $\mathrm{rt}$ for $1 \mathrm{~h}$. The reaction was diluted with $\mathrm{MeOH}(1 \mathrm{~mL})$ to give a $70 \%$
$\mathrm{DMF} / \mathrm{MeOH}$ mixture. Purification by reverse phase chromatography gave, after concentration and lyophilization, $0.141 \mathrm{~g}$ (71\% yield) of $(S)$-24 as a fluffy, white solid. Analytical HPLC Purity, 99.4\%. HRMS m/z calc'd for $\mathrm{C}_{31} \mathrm{H}_{27} \mathrm{ClN}_{7} \mathrm{O}_{3}(\mathrm{M}+$ $\mathrm{H})^{+}$: 580.1858. Found 580.1876. LCMS m/z $580.3(\mathrm{M}+\mathrm{H})^{+}$and $582(\mathrm{M}+2+\mathrm{H})^{+} .{ }^{1} \mathrm{H}$ NMR $\left(500 \mathrm{MHz}, \mathrm{DMSO}_{-} \mathrm{d}_{6}\right) \delta: 9.97(\mathrm{~s}, 1 \mathrm{H})$, $9.84(\mathrm{~s}, 1 \mathrm{H}), 8.86(\mathrm{~d}, J=8.2 \mathrm{~Hz}, 1 \mathrm{H}), 8.63(\mathrm{~d}, J=5.5 \mathrm{~Hz}, 1 \mathrm{H})$, $7.97(\mathrm{~d}, J=2.2 \mathrm{~Hz}, 1 \mathrm{H}), 7.82-7.76(\mathrm{~m}, 4 \mathrm{H}), 7.75(\mathrm{dd}, J=8.8$, $2.2 \mathrm{~Hz}, 1 \mathrm{H}), 7.71(\mathrm{~d}, J=8.8 \mathrm{~Hz}, 1 \mathrm{H}), 7.64(\mathrm{~d}, J=8.8 \mathrm{~Hz}, 2 \mathrm{H})$, $7.28-7.23(\mathrm{~m}, 2 \mathrm{H}), 7.22-7.15(\mathrm{~m}, 3 \mathrm{H}), 6.86(\mathrm{~d}, J=15.4 \mathrm{~Hz}$, $1 \mathrm{H}), 6.81(\mathrm{~d}, J=15.4 \mathrm{~Hz}, 1 \mathrm{H}), 5.34-5.28(\mathrm{~m}, 1 \mathrm{H}), 3.70(\mathrm{~s}, 3 \mathrm{H})$, $3.20(\mathrm{dd}, J=13.7,6.0 \mathrm{~Hz}, 1 \mathrm{H}), 3.12(\mathrm{dd}, J=13.7,8.8 \mathrm{~Hz}, 1 \mathrm{H})$. ${ }^{13} \mathrm{C}$ NMR (125 MHz, DMSO-d 6 ) $\delta: 163.7,159.4,153.9,150.4$ (bs), 146.2 (bs), 145.2, 141.5, 137.5, 135.8, 132.9, 130.95, $130.92,130.2,129.4,129.2,129.0,128.2,128.0,127.4,127.0$, $126.5,120.1,119.1,118.4,54.8,51.8,40.4 \cdot[\alpha]_{\mathrm{D}}^{23.6}=9.82(\mathrm{c}$ $=1.16$, DMSO). Anal. calcd for $\mathrm{C}_{31} \mathrm{H}_{26} \mathrm{ClN}_{7} \mathrm{O}_{3} \cdot 0.94 \mathrm{H}_{2} \mathrm{O} \cdot 0.92$ $\mathrm{C}_{2} \mathrm{HF}_{3} \mathrm{O}_{2}$ : C, 56.20; H, 4.14; N, 13.97; F, 7.47; Cl, 5.05. Found: C, 56.50; H, 4.25; N, 13.78; F, 7.63; Cl, 4.96.

\subsubsection{Methyl $N$-(4-\{4-[(1S)-1-[(2E)-3-[5-chloro-2-(1H-} 1,2,3,4-tetrazol-1-yl)phenyl]prop-2-enamido]-2-phenylethyl]pyridin-2-yl\}phenyl)carbamate, trifluoroacetic acid salt $[(S)$ 25].

To a solution of $(S)-7 \mathrm{~g}(0.029 \mathrm{~g}, 0.069 \mathrm{mmol})$ in DMF $(1 \mathrm{~mL})$ was added (2E)-3-[5-chloro-2-(1H-1,2,3,4-tetrazol-1-yl)phenyl]prop-2-enoic acid (7c, $0.017 \mathrm{~g}, 0.069 \mathrm{mmol}), \mathrm{EDC}(0.026 \mathrm{~g}, 0.14$ $\mathrm{mmol})$, HOBt $(0.021 \mathrm{~g}, 0.14 \mathrm{mmol})$ and TEA $(0.048 \mathrm{~mL}, 0.34$ $\mathrm{mmol})$. The reaction mixture was stirred at $\mathrm{rt}$. After $18 \mathrm{~h}$, the reaction was diluted with $\mathrm{MeOH}(3 \mathrm{~mL})$. Purification by reverse phase chromatography gave, after concentration and lyophilization, $0.036 \mathrm{~g}$ (75\% yield) of $(S)-\mathbf{2 5}$ as an off-white solid. Analytical HPLC Purity, 99.5\%. LCMS: $580.0(\mathrm{M}+\mathrm{H})^{+}$. ${ }^{1} \mathrm{H} \mathrm{NMR}\left(400 \mathrm{MHz}, \mathrm{CD}_{3} \mathrm{OD}\right) \delta$ : 9.75 (s, 1H), 9.48 (s, 1H), 9.09 $9.05(\mathrm{~m}, 1 \mathrm{H}), 8.62(\mathrm{~d}, J=6.6 \mathrm{~Hz}, 1 \mathrm{H}), 8.02(\mathrm{~s}, 1 \mathrm{H}), 7.97(\mathrm{~d}, J=$ $2.2 \mathrm{~Hz}, 1 \mathrm{H}), 7.80-7.71(\mathrm{~m}, 5 \mathrm{H}), 7.66(\mathrm{dd}, J=8.8,2.2 \mathrm{~Hz}, 1 \mathrm{H})$, $7.56(\mathrm{~d}, J=8.2 \mathrm{~Hz}, 1 \mathrm{H}), 7.32-7.21(\mathrm{~m}, 5 \mathrm{H}), 7.07$ (d, $J=15.4$ $\mathrm{Hz}, 1 \mathrm{H}), 6.73$ (d, $J=15.9 \mathrm{~Hz}, 1 \mathrm{H}), 5.44-5.37(\mathrm{~m}, 1 \mathrm{H}), 3.78$ (s, $3 \mathrm{H}), 3.30$ - $3.24(\mathrm{~m}, 1 \mathrm{H})$ partial overlap with $\mathrm{CD}_{3} \mathrm{OD}, 3.19$ (dd, $J$ $=13.7,7.1 \mathrm{~Hz}, 1 \mathrm{H})$.

\subsubsection{Methyl $N$-(4-\{6-[(1S)-1-[(2E)-3-[5-chloro-2-(1H-} 1,2,3,4-tetrazol-1-yl)phenyl]prop- 2-enamido]-2-phenylethyl]pyrimidin-4-yl\}phenyl)carbamate, trifluoroacetic acid salt $[(S)-26]$.

To a suspension of $(S)$-6d $(0.035 \mathrm{~g}, 0.076 \mathrm{mmol})$ and 2,5-dioxopyrrolidin-1-yl (2E)-3-[5-chloro-2-(1H-1,2,3,4-tetrazol1-yl)phenyl]prop-2-enoate (7d, $0.026 \mathrm{~g}, 0.076 \mathrm{mmol})$ in DMF $(0.757 \mathrm{~mL})$ was added Hunig's base $(0.066 \mathrm{~mL}, 0.378 \mathrm{mmol})$. The resulting clear, slightly yellow solution was stirred at rt. After $3 \mathrm{~h}$, the reaction was partitioned between EtOAc/water and the layers were separated. The aqueous layer was extracted with EtOAc $(1 \mathrm{x})$. The organic layers were combined and washed with sat. $\mathrm{NaHCO}_{3}$, brine, dried over $\mathrm{Na}_{2} \mathrm{SO}_{4}$, filtered and concentrated to give a greenish solid. Purification by reverse phase chromatography gave, after concentration and lyophilization, $0.0281 \mathrm{~g}$ (64\% yield) of $(S)-26$ as a pale, yellow solid. Analytical HPLC Purity, 99.5\%. LCMS: $581.1(\mathrm{M}+\mathrm{H})^{+} .{ }^{1} \mathrm{H}$ NMR (400 MHz, DMSO-d $)_{6}$ ) : 10.02 (s, 1H), 9.85 (s, 1H), 9.14 (s, $1 \mathrm{H}), 8.84(\mathrm{~d}, J=8.3 \mathrm{~Hz}, 1 \mathrm{H}), 8.11(\mathrm{~d}, J=8.8 \mathrm{~Hz}, 2 \mathrm{H}), 7.98$ $(\mathrm{d}, J=2.2 \mathrm{~Hz}, 1 \mathrm{H}), 7.91(\mathrm{~s}, 1 \mathrm{H}), 7.75(\mathrm{dd}, J=8.3,1.8 \mathrm{~Hz}, 1 \mathrm{H})$, $7.71(\mathrm{~d}, J=8.8 \mathrm{~Hz}, 1 \mathrm{H}), 7.63(\mathrm{~d}, J=8.8 \mathrm{~Hz}, 2 \mathrm{H}), 7.29-7.15(\mathrm{~m}$, $5 \mathrm{H}), 6.87(\mathrm{~d}, J=15.8 \mathrm{~Hz}, 1 \mathrm{H}), 6.81(\mathrm{~d}, J=15.8 \mathrm{~Hz}, 1 \mathrm{H}), 5.26-$ $5.17(\mathrm{~m}, 1 \mathrm{H}), 3.69(\mathrm{~s}, 3 \mathrm{H}), 3.18(\mathrm{dd}, J=13.6,5.7 \mathrm{~Hz}, 1 \mathrm{H}), 3.05$ $(\mathrm{dd}, J=13.6,9.2 \mathrm{~Hz}, 1 \mathrm{H})$. 


\subsection{X-Ray Crystallography}

X-ray crystal structure data collection and structure refinement (see Supplemental Information Tabulated Parameters). Protein for Factor XIa crystals in complex with inhibitors $(S)$-10 and $(S)$-17 was prepared as previously described. ${ }^{16}$ Data for these crystals were collected in the laboratory. Raw data were processed with the program HKL2000. ${ }^{40}$ The atomic coordinates of human Factor XIa (PDB ID 4NA8) were used as a search model for rigid body only refinement in AmoRe. ${ }^{41-43}$ Original refinement for compounds was carried out with CNX (Accelrys) and inhibitor restraint dictionaries were built with QUANTA (Accelrys), which was also used for modeling. Later the structures were re-refined using BUSTER/TNT ${ }^{44}$ (GlobalPhasing, Ltd.), MakeTNT (GlobalPhasing, Ltd., Cambridge, UK) for inhibitor restraint dictionaries, and $\mathrm{COOT}^{44}$ for modeling. Protein for Factor XIa in complex with inhibitor $(S)$-24 was purchased from Proteros biostructures GmbH (Martinsried, Germany). Data were collected at the Advanced Photon Source (APS) beamline 17-ID and processed with $\mathrm{XDS}^{46,47}$ and AIMLESS ${ }^{48}$ through the use of autoPROC (GlobalPhasing, Ltd., Cambridge, UK). The atomic coordinates of human Factor XIa derived from PDB ID 3SOR were used as search model for rigid body only refinement in AmoRe. ${ }^{41-43}$ The structure was refined with BUSTER/TNT ${ }^{44}$ (GlobalPhasing, Ltd.), GRADE (GlobalPhasing, Ltd., Cambridge, UK) for inhibitor restraint dictionaries, and $\mathrm{COOT}^{45}$ for modeling. The PDB deposition numbers for compounds $(S)$ 10, $(S)$-17, and $(S)$-24 complexed to FXIa are 5EXL, 5EXM, and $5 \mathrm{EXN}$, respectively.

\subsection{Enzyme and Coagulation Assays}

The affinity of compounds for various enzymes was determined using purified enzymes and synthetic peptide substrates from commercial sources. The $\mathrm{IC}_{50}$ values were obtained over 4-11 inhibitor concentrations assayed in duplicate at a fixed substrate concentration with a standard error of $<20 \%$. $\mathrm{Ki}$ values were calculated using the relationship $\mathrm{Ki}$ equals $\mathrm{IC}_{50}$ divided by $(1+\mathrm{S} / \mathrm{Km})$, assuming competitive inhibition, where $\mathrm{S}$ is the concentration of substrate, and $\mathrm{Km}$ is the Michaelis-Menten constant for the substrate.

The aPTT (activated partial thromboplastin time) in vitro clotting assay was performed in an automated coagulation analyzer using pooled normal human plasma and reagents from commercial sources. The reported $\mathrm{EC}_{1.5 \mathrm{x}}$ values are the FXIa inhibitor plasma concentrations which produce a $50 \%$ increase in the clotting time relative to the clotting time in the absence of the inhibitor.

Please see reference $15 \mathrm{~b}$ for a complete description of the in vitro enzyme and plasma coagulation assays.

\section{Acknowledgments}

The authors would like to thank Dauh-Rurng $\mathrm{Wu}$, Leslie W. Leith, Peng Li, Atsu Apedo, and Douglas B. Moore for chiral separations of intermediates; the Department of Discovery Synthesis and BMS Biocon Research Center for the preparation of synthetic intermediates; the Department of Lead Discovery \& Optimization. Jeffrey M. Bozarth and Frank A. Barbera for in vitro work; Mei-Mann Hsueh, Gang Lou, Zhen Lou, Qinling Qu, and Baomin Xin for PK studies and analyses; William Ewing for proof reading the manuscript. Use of the IMCA-CAT beamline
17-ID at the Advanced Photon Source was supported by the companies of the Industrial Macromolecular Crystallography Association through a contract with the Illinois Institute of Technology. Use of the Advanced Photon Source was supported by the U. S. Department of Energy, Office of Science, Office of Basic Energy Sciences, under Contract No. DE-AC02$06 \mathrm{CH} 11357$.

\section{Supplementary Material}

Analytical data and experimental procedures for intermediates 1d-1g, 2g, 2h, 3c, 3e, 4a, 4g, 4h, (S)-5a, (S)-5b, 5d, (S)-5e, (S)5f, 5h, 5i, (S)-5j, 8b, and (S)-8d; Analytical data and experimental procedures for final compounds 3-4, $(S)-5,6-9,11-$ 16, (S)-18 to (S)-20, (S)-22, and (S)-27; and Crystallographic data and refinement statistics for X-ray structures of the FXIa complexes with compounds $(S)-\mathbf{1 0},(S)-\mathbf{1 7}$, and $(S)-\mathbf{2 4}$.

\section{References and notes}

1. Bane, C.E.; Gailani, D. Drug Discovery Today 2014, 19 (9), 14541458.

2. Bane, C.E.; Neff, A.T.; Gailani, D. In Hemostasis and Thrombosis: Practical Guidelines in Clinical Management; Saba, H.I., Roberts, H.R., Eds.; John Wiley \& Sons, Ltd.: Oxford, 2014; pp 71-81.

3. (a) Salomon, O.; Steinberg, D.M.; Koren-Morag, N.; Tanne, D.; Seligsohn, U. Blood 2008, 111 (8), 4113-4117. (b) Salomon, O.; Steinberg, D.M.; Dardik, R.; Rosenberg, N.; Zivelin, A.; Tamarin, I.; Ravid, B.; Berliner, S.; Seligsohn, U. J. Thromb. Haemost. 2003, 1, 658-661. (c) Salomon, O.; Steinberg, D.M.; Zucker, M.; Varon, D.; Zivelin, A.; Seligsohn, U. Thromb. Haemost. 2011, 105, 269-273.

4. (a) Doggen, C.J.M; Rosendaal, F.R.; Meijers, J.C.M. Blood 2006, 108 (13), 4045-4051. (b) Meijers, J.C.M.; Tekelenburg, W.L.H.; Bouma, B.N.; Bertina, R.M.; Rosendaal, F.R. N. Eng. J. Med. 2000, 342(10), 696-701.

5. (a) Wang, X.; Smith, P.L.; Hsu, M-Y.; Gailani, D.; Schumacher, W.A.; Ogletree, M.L.; Seiffert, D.A. J. Thromb. Haemost. 2006, 4, 1982-1988. (b) Wang, X.; Cheng, Q.; Xu. L.; Feuerstein, G.Z.; Hsu, M-Y.; Smith, P.L.; Seiffert, D.A.; Schumacher, W.A.; Ogletree, M.L.; Gailani, D. J. Thromb. Haemost. 2005, 3, 695702. (c) Rosen, E.D.; Gailani, D.; Castellino, F.J. Thromb. Haemost. 2002, 87, 774-776.

6. (a)Yamashita, A.; Nishihira, K.; Kitazawa, T.; Yoshihashi, K.; Soeda, T.; Esaki, K.; Imamura, T.; Hattori, K.; Asada, Y. J. Thromb. Haemost. 2006, 4, 1496-1501. (b) Tucker, E.I.; Marzec, U.M.; White, T.C.; Hurst, S.; Rugonyi, S.; McCarty, O.J.T.; Gailani, D.; Gruber, A.; Hanson, S.R. Blood 2009, 113 (4), 936944. (c) Gruber, A.; Hanson, S.R. Blood 2003, 102 (3), 953-955.

7. (a) Crosby, J.R.; Marzec, U.; Revenko, A.S.; Zhao, C.; Gao, D.; Matafonov, A.; Gailani, D.; MacLeod, A.R.; Tucker, E.I.; Gruber, A.; Hanson, S.; Monia, B.P. Arterioscler. Thromb. Vasc. Biol. 2013, 33, 1670-1678. (b) Zhang, H.; Lowenberg, E.C.; Crosby, J.R.; MacLeod, A.R.; Zhao, C.; Gao, D.; Black, C.; Revenko, A.S.; Meijers, J.C.M., Stroes, E.S.; Levi, M.; Monia, B.P. Blood 2010, 116, 4684-4692.

8. Buller, H.R.; Bethune, C.; Bhanot, S.; Gailani, D.; Monia, B.P.; Raskob, G.E.; Segers, A.; Verhamme, P.; Weitz, J.I. N. Engl. J. Med. 2015, 372, 232-240. The FXI ASO work published subsequent to the work described herein.

9. (a)Schumacher, W.A.; Seiler, S.E.; Steinbacher, T.E.; Stewart, A.B.; Bostwick, J.S.; Hartl, K.S.; Liu, E.C.; Ogletree, M.L. Eur. J. Pharmacol. 2007, 570, 167-174. (b) Wong, P.C.; Crain, E.J.; Watson, C.A.; Schumacher, W.A. J. Thromb. Thrombolysis 2011, 32, 129-137.

10. (a) Deng, H.; Bannister, T.D.; Jin, L.; Babine, R.E.; Quinn, J.; Nagafuji, P.; Celatka, C.A.; Lin, J.; Lazarova, T.I.; Rynkiewicz, M.J.; Bibbins, F.; Pandey, P.; Gorga, J.; Meyers, H.V.; AbdelMeguid, S.S.; Strickler, J.E. Bioorg. Med. Chem. Lett. 2006, 16, 3049-3054. (b) Lin, J.; Deng, H.; Jin, L.; Pandey, P.; Quinn, J.; Cantin, S.; Rynkiewicz, M.J.; Gorga, J.C.; Bibbins, F.; Celatka, C.A.; Nagafuji, P.; Bannister, T.D.; Meyers, H.V.; Babine, R.E.; Hayward, N.J.; Weaver, D.; Benjamin, H.; Stassen, F.; AbdelMeguid, S.S.; Strickler, J.E. J. Med. Chem. 2006, 49, 7781-7791. 
11. Lazarova, T.I.; Jin, L.; Rynkiewicz, M.; Gorga, J.C.; Bibbins, F.; Meyers, H.V.; Babine, R.; Strickler, J. Bioorg. Med. Chem. Lett. 2006, 16, 5022-5027.

12. Buchanan, M.S.; Carroll, A.R.; Wessling, D.; Jobling, M.; Avery, V.M.; Davis, R.A.; Feng, Y.; Xue, Y.; Oster, L.; Fex, T.; Deinum, J.; Hooper, J.N.A.; Quinn, R.J. J. Med. Chem. 2008, 51, 35833587.

13. It is not clear whether the macrocyclic indole from Hannesian is an irreversible inhibitor, however, it was only weakly active against FXIa $($ FXIa $\mathrm{Ki}=51.6 \mu \mathrm{M})$, please see. Hanessian, S. Larsson, A.; Fex, T.; Knecht, W.; Blomberg, N. Bioorg. Med. Chem. Lett. 2010, 20, 6925-6928.

14. Al-Horani, R.A.; Desai, U.R. J. Med. Chem. 2014, 57(11), 48054818. (g) Sinha, D.; Badellino, K.O.; Marcinkiewicz, M.; Walsh, P.N. Biochemistry 2004, 43, 7593-7600.

15. (a) Wong, P. C.; Quan, M. L.; Watson, C.; Crain, E.; Wexler, R. R.; Seiffert, D. Presented at the American Heart Association Scientific Sessions, Dallas, TX, Nov. 2013; APS.709.03, Poster \#7050. (b) Quan, M.L.; Wong, P.C.; Wang, C.; Woerner, F.; Smallheer, J.M.; Barbera, F.A.; Bozarth, J.M.; Brown, R.L.; Harpel, M.R.; Luettgen, J.M.; Morin, P.E.; Peterson, T.; Ramamurthy, V.; Rendina, A.R.; Rossi, K.A.; Watson, C.A.; Wei, A.; Zhang, G.; Seiffert, D.; Wexler, R.R. J. Med. Chem. 2014, 57(3), 955-969. (c) Wong, P.C.; Quan, M.L.; Watson, C.A.; Crain, E.J.; Harpel, M.R.; Rendina, A.R.; Luettgen, J.M.; Wexler, R.R.; Schumacher, W.A.; Seiffert, D.A. J. Thromb. Thrombolysis 2015, 40(4), 416-423.

16. Hangeland, J.J.; Friends, T.J.; Rossi, K.A.; Smallheer, J.M.; Wang, C.; Sun, Z.; Corte, J.R.; Fang, T.; Wong, P.C.; Rendina, A.R.; Barbera, F.A.; Bozarth, J.M.; Luettgen, J.M.; Watson, C.A.; Zhang, G.; Wei, A.; Ramamurthy, V.; Morin, P.E.; Bisacchi, G.S.; Subramaniam, S.; Arunachalam, P.; Mathur, A.; Seiffert, D.A.; Wexler, R.R.; Quan, M.L. J. Med. Chem. 2014, 57, 9915-9932.

17. Pinto, D.J.P; Smallheer, J.M.; Corte, J.R.; Austin, E.J.D.; Wang, C.; Fang, T., Smith, L.M.; Rossi, K.A.; Rendina, A.R.; Bozarth, J.M.; Zhang, G.; Wei, A.; Ramamurthy, V.; Sheriff, S.; Myers, J.E.; Morin, P.E.; Luettgen, J.M.; Seiffert, D.A.; Quan, M.L.; Wexler, R.R. Bioorg. Med. Chem. Lett. 2015, 25, 1635-1642. It should be noted that less potent FXIa inhibitors (FXIa Ki $=65-200$ $\mathrm{nM})$ were also shown to be orally bioavailable $(\% \mathrm{~F}=26-49 \%)$, however, imidazole $(S)$-23 provided the best combination of FXIa $\mathrm{Ki}$ and $\% \mathrm{~F}$.

18. Corte, J.R.; Fang, T.; Hangeland, J.J.; Friends, T.J.; Rendina, A. R.; Luettgen, J.M.; Bozarth, J.M.; Barbera, F.A.; Rossi, K.A.; Wei, A.; Ramamurthy, V.; Morin, P.E.; Seiffert, D.A.; Wexler, R.R.; Quan, M.L. Bioorg. Med. Chem. Lett. 2015, 25, 925-930.

19. Baiocchi, L.; Corsi, G.; Palazzo, G. Synthesis 1978, 633-648. The 3-hydroxy indazole can also exist as the 3-oxo tautomer. If the 3oxo tautomer predominates, electrostatic repulsion exists between the 3-oxo and the carbonyl of His 40 and/or the conserved water. Similarly if the 3-hydroxy tautomer predominates, the hydroxyl could maintain one H-bond, however, the oxygen lone pair would undergo electrostatic repulsion with either the carbonyl of His40 or the water.

20. The enantiomer $(R)-5$ had a FXIa $\mathrm{Ki}=3,197 \mathrm{nM}$

21. The presence of ethylene diol (EDO) is an artifact of the crystallization process.

22. Subsequent to our work, 1-acylindazol-3-ols were used as a bioisostere for an anthranilic acid. See: Stiff, C.; Graber, D.R.; Thorarensen, A.; Wakefield, B.D.; Marotti, K.R.; Melchior, E.P.; Sweeney, M.T.; Han, F.; Rohrer, D.C.; Zurenko, G.E.; Romero, D.L. Bioorg. Med. Chem. Lett. 2008, 18, 6293-6297.

23. The protein binding for $(S)-\mathbf{2},(S)-\mathbf{5},(S)-\mathbf{1 0}$, and $(S)$-17 was not determined. The protein binding for compounds $(S)-\mathbf{2 4}$ to $(S)-27$ was not determined. However, based on unpublished data from our Factor Xa and Factor XIa programs, protein binding does impact the translation of Ki into the clotting assay. Specifically poor translation into the clotting assay is at least in part due to high protein binding.

24. An X-ray structure of $(S)-22$ bound to Factor XIa, unpublished result, indicated that the carbonyl of the pyridinone scaffold was picking up H-bonds with both Lys192 and Tyr143 through water molecules and may explain the 2.5-fold increase in FXIa binding relative to the pyridine $(S)$-17 scaffold. In addition, absolute stereochemistry was confirmed to be (S).

25. Young, M.B.; Barrow, J.C.; Glass, K.L.; Lundell, G.F.; Newton, C.L.; Pellicore, J.M.; Rittle, K.E.; Selnick, H.G.; Stauffer, K.J.; Vacca, J.P.; Williams, P.D.; Bohn, D.; Clayton, F.C.; Cook, J.J.; Kruger, J.A.; Kuo, L.C.; Lewis, S.D.; Lucas, B.J.; McMasters,
D.R.; Miller-Stein, C.; Pietrak, B.L.; Wallace, A.A.; White, R.B.; Wong, B.; Yan, Y.; Nantermet, P.G. J. Med. Chem. 2004, 47, 2995-3008. The chlorophenyltetrazole moiety was first identified in thrombin inhibitors and the authors propose that the tetrazole ring interacts with the disulfide bridge via a donor atom- $\pi$ interaction.

26. Pinto, D. J. P.; Orwat, M. J.; Koch, S.; Rossi, K. A.; Alexander, R. S.; Smallwood, A.; Wong, P. C.; Rendina, A. R.; Luettgen, J. M.; Knabb, R. M.; He, K.; Xin, B.; Wexler, R. R.; Lam, P. Y. S. J. Med. Chem. 2007, 50(22), 5339-5356.

27. The improvement in plasma kallikrein selectivity can be attributed to the difference in an amino acid at position 143 in the S2 prime pocket. Plasma kallikrein possesses a Phe143 whereas Factor XIa contains Tyr143. The 3-hydroxyl indazole $\mathrm{P} 2$ prime moiety is not as active in plasma kallikrein since it cannot form an $\mathrm{H}$-bond to Phe143

28. The improvement in trypsin selectivity can be attributed to the difference in the size of the $\mathrm{S} 1$ pocket between trypsin and Factor XIa. The S1 pocket of FXIa is slightly larger and more lipophilic than trypsin so it can accommodate the larger chlorophenyltetrazole P1. Please see, Colman, R. W.; Hirsch, J.; Marder, V. J. Hemostasis and Thrombosis: Basic Principles and Clinical Practice; Lippincott: Philadelphia, 1994.

29. Negi, S.; Matsukura, M.; Mizuno, M.; Miyake, K.; Minami, N. Synthesis 1996, 991-996.

30. Each enantiomer was reacted with $(S)-(+)-\alpha$-methoxyphenyl acetic acid according to Trost (Trost, B.M. et al., J. Org. Chem. 1994, 59, 4202.) for determination of the absolute stereochemistry. The absolute stereochemistry was confirmed by X-ray crystallography of $(S)-\mathbf{1 0},(S)-\mathbf{1 7}$, and $(S)$-24 bound to FXIa.

31. Schlosser, M.; Cottet, F. Eur. J. Org. Chem. 2002, 24, 4181-4184

32. Palermo, M.G. Tetrahedron Lett. 1996, 37(17), 2885-2886.

33. Hart, D.J.; Kanai, K.; Thomas, D.G.; Yang, T-K. J. Org. Chem. 1983, 48(3), 289-294.

34. Maibaum, J.; Rich, D.H. J. Org. Chem. 1988, 53, 869-873.

35. Butters, M. J. Heterocycl. Chem. 1992, 29, 1369-1370.

36. Kuduk, S.D.; DiPardo, R.M.; Chang, R.K.; Ng, C.; Bock, M.G. Tetrahedron Lett. 2004, 45, 6641-6643.

37. Rodriguez, A.C.; Ramos, A.P.; Hawkes, G.E.; Berti, F.; Resmini, M. Tetrahedron: Asymmetry 2004, 15(12), 1847-1855.

38. Racemization of either the starting material or the intermediates to the pyridinone occurred under the reaction conditions.

39. Howard, N.; Abell, C.; Blakemore, W.; Chessari, G.; Congreve, M.; Howard, S.; Jhoti, H.; Murray, C.W.; Seavers, L.C.A.; van Montfort, R.L.M. J. Med. Chem. 2006, 49, 1346-1355.

40. Otwinowski, Z.; Minor, W. Macromolecular Crystallography. Part A; Carter, C.W., Sweet, R.M., Eds.; Methods in Enzymol. Vol. 276; Academic Press, Inc., San Diego, CA, 1997; pp 307-326.

41. Navaza, J. Acta Crystallogr. Sect. A 1994, 50, 157-163.

42. Navaza, J.; Vernoslova, E. Acta Crystallogr. Sect. A 1995, 51, 445-449

43. Collaboration Computational Project, Number 4. The CCP4 Suite: programs for protein crystallography. Acta Crystallogr Sect. D 1994, 50, 760-763.

44. Blanc, E.; Roversi, P.; Vonrhein, C.; Flensburg, C.; Lea, S. M.; Bricogne, G. Acta Crystallogr., Sect. D: Biol. Crystallogr. 2004, 60, 2210-2221

45. Emsley, P.; Lokhamp, B.; Scott, W.G.; Cowtan, K. Acta Crystallogr., Sect. D: Biol. Crystallogr. 2010, 66, 486-501.

46. Kabsch, W. Acta Crystallogr. Sect. D Biol. Crystallogr. 2010, 66, 125-132

47. Kabsch, W. Acta Crystallogr. Sect. D Biol. Crystallogr. 2010, 66, 133-144.

48. Evans, P.R.; Murshudov, G.N. Acta Crystallogr. Sect. D Biol. Crystallogr. 2013, 69, 1204-1214. 


\section{Graphical Abstract}

\section{Orally Bioavailable Pyridine and \\ Pyrimidine-Based Factor XIa Inhibitors: \\ Discovery of the Methyl N-Phenyl \\ Carbamate P2 Prime Group}

James R. Corte*, Tianan Fang, Donald J. P. Pinto, Michael J. Orwat, Alan R. Rendina, Joseph M. Luettgen,

Karen A. Rossi, Anzhi Wei, Vidhyashankar Ramamurthy, Joseph E. Myers Jr., Steven Sheriff, Rangaraj

Narayanan, Timothy W. Harper, Joanna J. Zheng, Yi-Xin Li, Dietmar A. Seiffert, Ruth R. Wexler, and Mimi L.

Quan

Bristol-Myers Squibb Company, Research and Development, P.O. Box 5400, Princeton, New Jersey 08543,

United States

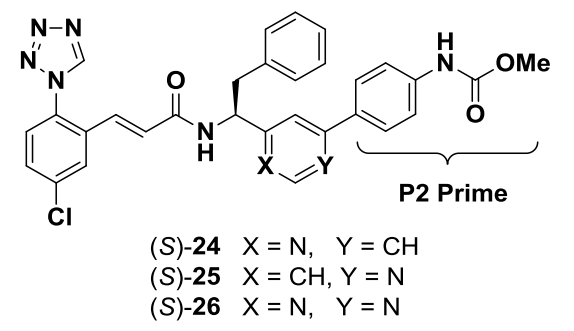

